\title{
Carbonate-to-biosilica transition at the Norian-Rhaetian boundary controlled by rift- related subsidence in the western Tethyan Lagonegro Basin (southern Italy)
}

Manuela Casacci ${ }^{1, *}$, Angela Bertinelli ${ }^{1}$, Thomas J. Algeo ${ }^{2,3, *}$, and Manuel Rigo ${ }^{4,5}$

\author{
${ }^{1}$ Department of Physics and Geology, University of Perugia, 06123, Perugia, Italy \\ ${ }^{2}$ Department of Geology, University of Cincinnati, Cincinnati, Ohio 45221-0013, USA \\ ${ }^{3}$ State Key Laboratories of GPMR and BGEG, China University of Geosciences, Wuhan, \\ China \\ ${ }^{4}$ Department of Geosciences, University of Padua, 35131, Padua, Italy \\ ${ }^{5}$ IGG - CNR, Via G. Gradenigo 6, 35131, Padua, Italy
}

Corresponding authors: manuela.casacci@studenti.unipg.it (MC); Thomas.Algeo@uc.edu (TJA)

\begin{abstract}
The Lagonegro Basin, located in the Southern Apennines, Italy, records a transition from carbonate sediments of the Calcari con Selce Fm. ("Cherty Limestone") to biosiliceous sediments of the Scisti Silicei Fm. ("Siliceous Shale") around the Norian-Rhaetian boundary (NRB), Upper Triassic. Sedimentologic and chemostratigraphic analysis of three sections (Pignola-Abriola, Monte Volturino, and Madonna del Sirino) representing a proximal-todistal transect across the basin document marine productivity, redox, and chemical weathering conditions. The basin was characterized by low to moderate productivity and mainly oxic deep waters, with no systematic secular variation throughout the $\sim 10$-Myr-long study interval. A weathering proxy, the chemical index of alteration (CIA*), shifts toward higher values (from $\sim 0.70$ to $\sim 0.80$ ) in all three study sections, suggesting development of warmer and/or more humid conditions just before the NRB. The lack of evidence for changes in marine productivity or redox conditions and the time-transgressive nature of the carbonatebiosilica transition suggests that the latter was caused not by changes in planktonic communities but, rather, by a rise in the CCD, the most likely cause of which was seafloor subsidence within the actively rifting Ionian Ocean (i.e., the westernmost branch of the
\end{abstract}


Tethys Ocean). The tectonically active character of the Lagonegro Basin is also reflected in evidence of synsedimentary paleoseismic activity, e.g., numerous debris flows around the basin margins. The present study thus documents sedimentologic changes within a marginal basin in a geologically young ocean.

Keywords: elemental geochemistry; rare earth elements; chemical index of alteration; redox conditions; Upper Triassic

\section{Introduction}

The breakup of the supercontinent Pangea started with rifting in modern eastern North America (Schlische et al., 2003), southern Iberia (Martin-Rojas et al., 2009), and western Morocco and the Atlas Mountains region in northwestern Africa (Dewey et al., 1973; Le Roy and Piqué, 2001; Schettino and Turco, 2009, 2011). In the western Tethyan region, this event was marked by the opening of multiple rift basins comprising the Ionian Ocean (Fig. 1). The kinematics of this rifting event resulted in the formation of a number of independent microplates (including the microplate called Adria) and pull-apart basins between Africa and Eurasia (Schettino and Turco, 2011). This first phase of rifting in the Ionian Ocean terminated at the Triassic/Jurassic boundary, when extension or spreading in the western Tethys ceased and Adria started to drift away from Eurasia. This event was coeval with a transition from radiolarite to siliceous carbonate sedimentation supplied by developing large carbonate platforms on the Ionian Ocean margins (Ciarapica and Passeri, 2005).

The Lagonegro Basin was located in the Ionian Ocean, the southernmost branch of the western Tethys (Finetti, 1982, 1985, 2003, 2005; Stampfli et al., 1991; Stampfli and Borel, 2002; Ciarapica and Passeri, 1998, 2002, 2005), at a paleolatitude of $28^{\circ} \mathrm{N}$ (Maron et al., 2015) during the Late Triassic (Fig. 1). Seismological studies have demonstrated that the Ionian Ocean was floored by oceanic crust as a consequence of rifting that began in the Permian and continued into the Triassic (Finetti, 2004). Today, its sedimentary record is exposed in the Southern Apennines of southern Italy. The Lagonegro Basin is one of the few areas that preserve Upper Triassic sediments from the Ionian Ocean domain, permitting analysis of the paleotectonic-oceanic developments in the western Mediterranean region during a key interval in the early breakup of Pangea (Passeri et al., 2005). The complex 
sedimentary successions that developed in the Lagonegro Basin during the Late Triassic reflect the interplay of contemporaneous tectonic and oceanic events in this region.

Upper Triassic sections of the Lagonegro Basin have been the subject of only limited geochemical study to date, providing insights regarding detrital siliciclastic provenance (Amodeo, 1999; Di Leo et al., 2002; Mongelli, 2004; Reggiani et al., 2005) but little information about marine productivity and redox conditions. Here, we present a detailed geochemical study of three sections (Pignola-Abriola, Monte Volturino, and Madonna del Sirino) representing a proximal-to-distal transect through Upper Norian and lower Rhaetian strata (Fig. 2). Our primary goal is to better understand the paleoceanographic evolution of the Lagonegro Basin in the context of rift-related subsidence and, in particular, the factors controlling the transition from carbonate sediments of the Calcari con Selce Fm. to biosiliceous sediments of the Scisti Silicei Fm. around the Norian-Rhaetian Boundary (NRB) (Fig. 3).

\section{Geological setting}

\subsection{Lagonegro Basin sedimentation}

The Lagonegro Basin accumulated shallow to deep basinal sediments from the Permian to the Miocene (Scandone, 1967). The early Middle Triassic (early Anisian) was characterized by regression, as shown by heightened terrigenous influx and stratigraphic lacunae of the Monte Facito Fm. (Ciarapica and Passeri, 2000; 2009). A second regression later in the Anisian is marked by turbiditic sandstones and reworked quartz-arenites. The Early Ladinian is characterized by a rapid shift to deeper conditions, as recorded by algal and stony coral bioherms overlain by red nodular limestones. Additional marine transgressions occurred from the late Middle Triassic through the Late Jurassic (Ciarapica and Passeri, 2000). Sea-level changes within the Lagonegro Basin were primarily connected with regional tectonic activity (e.g., basin-margin uplift, ocean-crust subsidence) and therefore do not conform to the global eustatic trend (Fig. 3).

During the Late Carnian and Early Norian, carbonate platforms bounded by steep slopes began to develop widely around the margins of the Lagonegro Basin (Fig. 2). At this time, sediments were mainly radiolarites and hemipelagic carbonates of the Calcari con Selce Fm. The abundance of micrite in this formation represents hemipelagic material derived from carbonate platforms (e.g., the Apenninic and Apulian platforms) that bordered the Lagonegro Basin to the west, north, and east (Fig. 1). This material was exported to deeper facies 
through basin-margin debris flows and basin-center nepheloid interflows (Passeri et al., 2005; Preto et al., 2012). From the Late Carnian, significant quantities of fine-grained pelagic carbonate were also contributed by nanoplankton (Scandone, 1967; Preto et al., 2012; 2013). Active tectonism, probably caused by extensional rifting, produced well-documented synsedimentary deformation features (Robertson et al., 1991; Ciarapica and Passeri, 1998; Ciarapica and Passeri, 2000; Finetti, 2003; Passeri et al., 2005). The basin was directly connected with the other Tethyan province basins (such as those of the Northern Alps, Taurides, Hellenides, and Dinarides, and also to the Imerese and Sicano basins in Sicily) (Fig. 1), as inferred from the shared occurrence of certain taxa (e.g., Halobia) in basinal successions of the circum-Mediterranean area (De Capoa Bonardi, 1984).

During the Upper Norian (Sevatian 1), an important change in sedimentation was recorded by the gradual transition from the Calcari con Selce Fm. to the Scisti Silicei Fm., marking a shift from predominantly carbonate to predominantly biosiliceous sedimentation (Fig. 3) (Reggiani et al., 2005; Rigo et al., 2012). This change probably occurred due to an increase in water depth beneath the local carbonate compensation depth (CCD) related to extensional tectonics in the Ionian Ocean and/or to a contemporaneous rise of the local CCD (Giordano et al., 2011). An earlier rise of the CCD occurred in the middle Carnian (Rigo et al., 2007), probably owing to climate change associated with the Carnian Pluvial Event (CPE), which coincided with an increase in sea-surface temperatures (Rigo and Joachimski, 2010; Rigo et al 2012; Trotter et al., 2015). During the Late Norian to Tithonian, the Lagonegro Basin accumulated deep-marine, mostly biosiliceous sediments at bathyal depths (Fig. 3). These characteristics reflect the evolution of the Lagonegro Basin in the context of broader tectonic-oceanic developments in the western Tethyan region during the Late Triassic, coinciding with fragmentation of the supercontinent Pangea (Passeri et al., 2005) (Fig. 1).

\subsection{Lagonegro Basin stratigraphy}

The Lagonegro Basin fill has been divided into a "Lower Sequence" comprising Permian-Lower Cretaceous units and an "Upper Sequence" comprising Upper CretaceousMiocene units (Fig. 2a) that are not in conformable contact with each other (Mostardini and Merlini, 1986). The Lower Sequence consists of the Monte Facito Fm. (Permian to Middle Triassic), Calcari con Selce Fm. (Middle Triassic to Upper Triassic), Scisti Silicei Fm. (Upper Triassic to Upper Jurassic), and "Flysch galestrino" (Upper Jurassic to Lower 
Cretaceous) (Mostardini and Merlini, 1986; Ciarapica and Passeri, 2005; Passeri and Ciarapica, 2010). Throughout the study region, the Lower Sequence is detached from its basement and now dissected into multiple tectonic units that were imbricated between the Apenninic and Apulian carbonate platforms during the Apennine orogeny (Mostardini and Merlini, 1986).

The Lower Sequence is found at two structural levels, i.e., the Lagonegro I and II tectonic units, as defined on the basis of geological profiles and seismological data by Scandone $(1967 ; 1972 ; 1975)$. Lagonegro II, which is imbricately thrust above Lagonegro I, represents the paleo-western portion of the basin (Amodeo, 1999). Differences in sedimentological characteristics imply a proximality gradient between these levels, with Lagonegro I exhibiting greater quantities of resedimented calcarenite and calcirudite from adjacent carbonate platforms in both the Calcari con Selce Fm. and Scisti Silicei Fm. and, hence, representing a more proximal part of the basin (i.e., closer to the northern basin margin) than Lagonegro II.

The Calcari con Selce Fm. and Scisti Silicei Fm. consist mainly of pelagic deposits bearing conodonts, pelagic bivalves, radiolarians, and rare ammonoids. Although both formations contain mixed carbonate and biosilica beds, the former are more abundant in the Calcari con Selce Fm. and the latter more abundant in the Scisti Silicei Fm. In more proximal areas of the Lagonegro Basin, deposition of the Calcari con Selce Fm. persisted until the Middle Jurassic (Selli, 1962; Scandone, 1967; Bertinelli et al., 2005a; Passeri et al., 2005). In the distal facies, the transition from carbonates of the Calcari con Selce Fm. to biosiliceous deposits of Scisti Silicei Fm. occurred during the Late Triassic (Late Norian-Rhaetian) or earliest Jurassic (Fig. 3). Owing to difficulties in locating the boundary between these formations, Miconnet (1983) first introduced the term "Transitional Interval" for that portion of the Lagonegro succession in which the upper part of the Calcari con Selce Fm. contains red radiolarite intercalations, which are typical of the overlying Scisti Silicei Fm. (Amodeo, 1999; Bertinelli et al., 2005a; Passeri et al., 2005; Reggiani et al., 2005). In the study area, the base of the "Transitional Interval" is conventionally marked by a 2- to 4-m-thick interval of red shales (Amodeo, 1999; Bertinelli et al., 2005b; Reggiani et al., 2005), a useful lithostratigraphic marker that is recognizable across the Lagonegro Basin. The base of this interval has been dated to Sevatian 1 (Mockina bidentata Zone) (Rigo et al., 2005; 2012). The beginning of deposition of the Scisti Silicei Fm. in the distal facies is defined by the first appearance of red radiolarite beds and has been dated to Sevatian 2 (Betraccium deweveri Zone) (Giordano et al., 2010). 


\subsection{Study sections}

The present study examines three sections that form a proximal-to-distal transect across the Lagonegro Basin (Fig. 2b). Pignola-Abriola represents a proximal part of the Lagonegro I tectonic unit, Monte Volturino represents a distal part of the same unit, and Madonna del Sirino represents a distal part of the Lagonegro II tectonic unit (Fig. 2a). All three sections consist mainly of $\mathrm{SiO}_{2}$ (about 50-60\%) and $\mathrm{CaCO}_{3}$ (about 20-30\%) with a very low content of clay minerals (about 10-20\%), as shown by whole-rock and glycolated XRD analysis of 22 samples of radiolarites and subordinately shales (see Supplementary Information). There are few differences between samples in terms of mineralogic composition, although the proportions of silica and carbonate vary considerably within and between the study sections. The silica and carbonate is largely of pelagic biogenic origin, although some carbonate material was shed from adjacent carbonate shelves as hemipelagic debris.

The Pignola-Abriola section crops out near the village of Pignola in the Mt. Crocetta area (Geographic coordinate system, datum WGS $84.40^{\circ} 33^{\prime} \mathrm{N} ; 15^{\circ} 47^{\prime} \mathrm{E}$ ). This site exposes cherty micritic limestone, silicified limestone, and rare dolostone beds belonging to the upper Calcari con Selce (Fig. 4a-b), within which is located the NRB (Amodeo et al., 1993; Amodeo, 1999; Bazzucchi et al., 2005; Rigo et al., 2005; Tanner et al., 2006). It is currently a candidate for the global stratotype section and point (GSSP) of the base of the Rhaetian stage (Rigo et al., 2015; Bertinelli et al., in press). It is considered to represent a proximal intermediate-depth setting within the Lagonegro Basin based on two characteristics: the lack of the red argillite interval that marks the base of the "Transitional Interval" and a relative abundance of calcarenite and calcirudites beds (Fig. 5). The basal $6 \mathrm{~m}$ of the section consist mainly of thin beds of cherty and nodular calcilutite that are locally dolomitized. The overlying strata comprise interbedded thinly stratified calcilutite containing brown chert nodules, and brownish-greenish argillite. The calcilutite beds represent hemipelagic sedimentation of fine carbonate derived from adjacent carbonate platforms, and the cherty nodules and layers formed through diagenetic remobilization of pelagic biosilica derived probably from radiolarians. The calcarenites represent grain flows or the basal (unit A) member of turbidites from adjacent carbonate platforms. Pignola-Abriola also contains thin (2 to $10 \mathrm{~cm}$ ) "black shales" (Fig. 4a-b), present mainly in the upper part of the section, that reflect accumulation of fine-grained siliciclastics under transiently reducing conditions. 
The Monte Volturino section represents an intermediate-depth setting at a location more distal than the Pignola-Abriola section (Fig. 2b) (Giordano et al., 2010; 2011). It crops out on the southern slope of Mt. Volturino (Geographic coordinate system, datum WGS 84. $40^{\circ} 24^{\prime} \mathrm{N} ; 1^{\circ} 49^{\prime}$ E) and exposes the uppermost Calcari con Selce and lowermost Scisti Silicei (Fig. 4c-d). The basal $4 \mathrm{~m}$ of this section contain red argillite beds that mark the base of the "Transitional Interval", followed by cherty limestones with red shale intercalations (Fig. 5). Strata in the overlying Scisti Silicei become thinner, consisting mainly of shales, chert beds, and some radiolarites and the youngest exposed strata at this site represent an alternation of brownish siliceous shales and silicified calcarenites. This section accumulated mainly through pelagic and hemipelagic sedimentation, although calcarenite layers in the upper part of the section were deposited as grain or turbidite flows (Giordano et al., 2011). These calcarenite layers comprise $\sim 10-12 \%$ of the Monte Volturino section, contributing to the greater thickness of its NRB transition interval relative to the other study sections (35 m versus $20-25 \mathrm{~m}$ ) and suggesting proportionately faster sedimentation rates. The large thickness of calcarenite layers in this section suggests proximity to an unknown carbonate shelf margin, but probably different from the one that influenced sedimentation at PignolaAbriola.

The Madonna del Sirino section represents a deeper, more distal part of the Lagonegro Basin than the other study sections (Fig. 2b) (Scandone, 1967; Amodeo, 1999; Bertinelli et al., 2005b; Passeri et al., 2005). It crops out on the east side of the town of Lagonegro, near the western slopes of Mt. Sirino (Geographic coordinate system, datum WGS $84.40^{\circ} 07^{\prime} \mathrm{N} ; 15^{\circ} 48^{\prime} \mathrm{E}$ ). It consists of the same stratigraphic units as the Monte Volturino section and it contains the same red argillite beds marking the base of the "Transitional Interval" (Fig. 4e-f). The lower half of the section is characterized by an alternation of limestone and cherty limestone with green argillites and some thin radiolarite beds that increase in frequency upward. Micritic carbonate disappears at the base of the Scisti Silicei, and the strata consist of red, brown, and black radiolarites with thin intercalations of red, green, grey and dark argillites (Fig. 5). The distal character of this section is inferred from a relative paucity of calcarenite beds derived from adjacent carbonate platforms (Fig. 5) (Amodeo, 1999; Reggiani et al., 2005).

The thermal maturity of the study region was investigated by Corrado et al. (2005). The Calcari con Selce and Scisti Silicei Formations as well as the underlying Monte Facito Fm. and overlying "Flysch galestrino" formation tended to yield similar values for each thermal maturity parameter. Vitrinite reflectance $\left(R_{\mathrm{o}}\right)$ is $1.76 \pm 0.33$, which is equivalent to a 
conodont color alteration index (CAI; Epstein et al., 1977) of 2.5-3.0 on standard conversion scales (e.g., Hartkopf-Froder et al., 2015). CAI values ranging from $~ 1.5$ to 4.0 have been reported for the study units (Bazzucchi et al., 2005; Giordano et al., 2010; Rigo et al., 2015), but the width of this range suggests variable conodont response to heating or, possibly, operator-specific outcomes. Other thermal maturity parameters include the percentage of illite in illite/smectite mixed layers (I/S), ranging from $55 \%$ to $100 \%$, the temperature of homogenization of fluid inclusions, ranging from 120 to 160 , and the Kübler index (KI), ranging from 0.65 to 1.10 (Corrado et al., 2005). These data broadly suggest burial temperatures of $125-175^{\circ} \mathrm{C}$ (Pollastro et al., 1993; Hunt, 1996).

\subsection{Biostratigraphy and correlations}

The Late Triassic is comprised of the Carnian, Norian and Rhaetian stages. The Late Norian, is divided into two substages, Sevatian 1 and 2, the bases of which coincide with the first appearance datums (FAD) of the conodonts Misikella bidentata and M. hernsteini, respectively (Rigo et al., 2015). The definition of the base of the Rhaetian Stage is still under debate, but the main marker proposed is the FAD of the conodont M. posthernsteini (Krystyn, 2010; Ogg, 2012; Rigo et al., 2015).

The biostratigraphy of the Lagonegro Basin has been investigated in a number of earlier studies. Scandone (1967, 1972) and De Capoa Bonardi (1984) described a rich fauna of bivalves, in particular the presence of various species of Halobia, in Carnian to Norian strata of the Calcari con Selce Fm. They also reported associations of Late Triassic to Late Jurassic foraminifera and radiolaria in the Scisti Silicei Fm. More recent work has established age constraints mainly on the basis of radiolarian and conodont biozonation (Bazzucchi et al., 2005; Reggiani et al., 2005; Giordano et al., 2010; 2011; Rigo et al., 2015) (Fig. 5) and magnetostratigraphic investigations (Maron et al., 2015).

At Pignola-Abriola, the NRB has been placed at the negative $\delta^{13} \mathrm{C}$ shift (Maron et al., 2015; Rigo et al., 2015) which is supported by the FAD (first appearance datum) of the conodont Misikella posthernsteini (Giordano et al., 2010; 2011) and falls therein the Proparvicingula moniliformis radiolarian Zone, two features that are regarded as useful indicators of the base of the Rhaetian (Gradstein et al., 2012). At Monte Volturino, the NRB was placed in the lower Scisti Silicei Fm., with a prominent negative shift recorded in the $P$. moniliformis radiolarian Zone (Rigo et al., 2015), which is $\sim 44 \mathrm{~m}$ above the base of the section (Giordano et al., 2010; 2011; Rigo et al., 2015). At Madonna del Sirino, the conodont 
Mockina bidentata has been found in the lower part of the section, indicating an Upper Norian (Sevatian 1) age for the Calcari con Selce Fm. (Reggiani et al., 2005). The Scisti Silicei Fm. has yielded various radiolarian taxa of early Rhaetian to Middle Jurassic age, and the Triassic/Jurassic boundary has been placed in the middle of the lower Scisti Silicei Fm. (Amodeo, 1999; Reggiani et al., 2005).

Given the superior biostratigraphic, magnetostratigraphic and geochemical constraints for the Pignola-Abriola section, we have correlated the other two study sections to it (Fig. 5). One correlation datum is a prominent negative shift in their $\delta^{13} \mathrm{C}_{\text {org }}$ profiles close to the NRB (Rigo et al., 2015), just below the FAD of the conodont $M$. posthernsteini and within the radiolarian Proparvicingula moniliformis Zone (Carter, 1993). Starting with this constraint, additional correlation tie-points were based on the $\mathrm{Ce} / \mathrm{Ce}^{*}$ profiles of the study sections. All of the sections show a trend of increasing $\mathrm{Ce} / \mathrm{Ce}^{*}$ values from the middle Sevatian 1 until just below the NRB, above which Ce/Ce* decreases (Pignola-Abriola and Monte Volturino) or continues to increase (Madonna del Sirino) (Fig. 6). Within the increasing trend below the $\mathrm{NRB}$, all sections show two pronounced minima in $\mathrm{Ce} / \mathrm{Ce} *$ that we adopt as correlation tiepoints $\mathrm{Tp} 1$ and $\mathrm{Tp} 2$. Because Ce in the study samples was derived mainly from detrital siliciclastic sediments (see below), Ce/Ce* ratios are useful as proxies for sediment provenance rather than watermass redox conditions. These correlations allowed us to refine the position of the NRB at Monte Volturino and Madonna del Sirino based on biostratigraphic data from the Pignola-Abriola section (i.e., the FAD of the conodont $M$. posthernsteini) (Fig. 5).

The absolute age of the study interval cannot be determined owing to uncertainties in the most recent international geologic time scale (Ogg, 2012), which offered both "Short Norian" and "Long Norian" age models, in which the NRB is dated to 209.0 Ma and 204.5 Ma, respectively. The more recent study of Wotzlaw et al. (2014) constrained the NRB to between 205.7 and 205.3 Ma based on high-precision zircon U-Pb dates, which is consistent with the magnetostratigraphic study of Maron et al. (2015). The Pignola-Abriola and Monte Volturino sections, which consist of Sevatian 1 and 2 and lowermost Rhaetian strata, are therefore estimated to have been deposited over intervals of $\sim 10$ and $\sim 8 \mathrm{Myr}$, respectively, on the basis of absolute ages calculated from the magnetostratigraphic profile of Maron et al. (2015). The Madonna del Sirino section is estimated to cover a slightly longer interval ( 11 Myr) but with greater uncertainties owing to lack of detailed biostratigraphic data. Given thicknesses of $50 \mathrm{~m}$ (Pignola-Abriola), $63 \mathrm{~m}$ (Monte Volturino), and $44 \mathrm{~m}$ (Madonna del Sirino), the average sedimentation rates for the study sections are in the range of 4-8 $\mathrm{m} \mathrm{Myr}^{-1}$, 
being somewhat higher at Monte Volturino relative to the other two sections. These rates are slower than those in typical epicontinental and continental shelf-margin sections ( $\sim 30 \mathrm{~m} \mathrm{Myr}^{-}$ ${ }^{1}$ ) and are closer to those in deep-sea sections dominated by pelagic depositional processes (Sadler, 1981).

\section{Methods}

Between 20 and 30 samples were collected from each section, sampling all major lithologies present. Samples with clear alteration by weathering were avoided. All samples were washed and powdered using an agate ball mill at the University of Perugia (Italy). Chemical analyses were carried out at the ACME laboratories in Vancouver, Canada. Total abundances of the major oxides and several minor elements $(\mathrm{Ni}, \mathrm{Sc}$, and $\mathrm{Cr})$ are reported on a $0.2 \mathrm{~g}$ sample analyzed by ICP-ES (inductively coupled plasma emission spectrometry) following a lithium metaborate/tetraborate fusion and dilute nitric digestion. Loss on ignition (LOI) is by weight difference after ignition at $1000^{\circ} \mathrm{C}$. Other trace elements and rare earth elements were analyzed by ICP-MS (inductively coupled plasma mass spectrometry) after the same process of fusion with $\mathrm{LiBO}_{2}$. Selected trace elements ( $\mathrm{Mo}, \mathrm{Cu}, \mathrm{Pb}, \mathrm{Zn}, \mathrm{As}, \mathrm{Cd}, \mathrm{Sb}, \mathrm{Bi}$, $\mathrm{Ag}, \mathrm{Au}, \mathrm{Hg}, \mathrm{Tl}$, and $\mathrm{Se}$ ) were measured by ICP-MS after sample splits of $0.5 \mathrm{~g}$ were leached in hot $\left(95^{\circ} \mathrm{C}\right)$ aqua regia. All techniques and processing methods followed ACME Laboratory guidelines. Total carbon and sulfur concentrations were measured using an Eltra $2000 \mathrm{C}-\mathrm{S}$ analyzer at the University of Cincinnati after digestion of samples in $2 \mathrm{~N} \mathrm{HCl}$ at $50^{\circ}$ for $12 \mathrm{~h}$ to dissolve carbonate minerals.

We calculated two marine productivity proxies, excess barium $\left(\mathrm{Ba}_{\mathrm{xs}}\right)$ and biogenic silica $\left(\mathrm{SiO}_{2(\mathrm{bio})}\right)$. Excess barium $\left(\mathrm{Ba}_{\mathrm{xs}}\right)$ was calculated as:

$$
\mathrm{Ba}_{\mathrm{xs}}=\mathrm{Ba}(\text { total })-\mathrm{Al} \times(\mathrm{Ba} / \mathrm{Al})_{\text {detrital }}
$$

where the units of $\mathrm{Ba} / \mathrm{Al}$ ratios are $10^{-4}$ (i.e., $\mathrm{ppm} / \%$ ). The detrital $\mathrm{Ba} / \mathrm{Al}$ ratio was determined separately for each section based on a section-specific regression of $\mathrm{Ba}$ against $\mathrm{Al}$. The inferred detrital $\mathrm{Ba} / \mathrm{Al}$ ratios for Pignola-Abriola (21), Monte Volturino (28), and Madonna del Sirino (28) are lower than commonly cited values for upper continental crust ( $65-75$; Dymond et al., 1992; McLennan, 2001) but within the range of values commonly reported for marine sediments (e.g., Schoepfer et al., 2014).

The biogenic silica concentration was calculated as:

$$
\mathrm{SiO}_{2 \text { (bio) }}=\mathrm{SiO}_{2 \text { (total) }}-\mathrm{A} 1 / 27.0 \times 2 \times 60.1
$$


where 27.0 and 60.1 are the atomic masses of $\mathrm{Al}$ and $\mathrm{SiO}_{2}$, respectively, and 2 is a molar conversion factor for TOT clay minerals, which contain two Si-bearing tetrahedral layers (T) for each Al-bearing octahedral layer $(\mathrm{O})$. This equation subtracts an estimated clay- $\mathrm{SiO}_{2}$ fraction from total $\mathrm{SiO}_{2}$, with the remainder representing a combination of biosilica, detrital quartz, and diagenetic chert. The present study units are known to contain large quantities of biosilica, primarily from radiolarians (Amodeo, 1999; Bertinelli et al., 2005a; Passeri et al., 2005; Reggiani et al., 2005), so the non-clay $\mathrm{SiO}_{2}$ fraction can be ascribed largely to this source.

We utilized the chemical index of alteration (CIA*), introduced by Nesbitt and Young (1982), as a proxy for chemical weathering intensity in terrestrial source areas. CIA is interpreted as a measure of the extent of conversion of feldspars (which dominate the upper crust) to clays such as kaolinite (Nesbitt and Young, 1984, 1989). It is expressed as a dimensionless number that usually ranges from $\sim 50-60$ for fresh rocks to 100 for completely weathered rocks, with average shale yielding values of $~ 70-75$ (Young and Nesbitt, 1998). In this study, we used a modified form of the CIA equation in which $\mathrm{CaO}$ is omitted from the denominator because of the high carbonate content of the study units, which makes it difficult to determine accurately the amount of non-carbonate $\mathrm{CaO}$ in each sample:

$$
\mathrm{CIA}^{*}=\mathrm{A}_{2} \mathrm{O}_{3} /\left(\mathrm{A}_{2} \mathrm{O}_{3}+\mathrm{Na}_{2} \mathrm{O}+\mathrm{K}_{2} \mathrm{O}\right) \times 100
$$

Ce anomaly is a ratio used to compare the behavior of Ce compared to their trivalent neighbors on the assumption that values close to 1.0 indicate a shale-like composition. These ratios were calculated as:

$$
\mathrm{Ce} / \mathrm{Ce}^{*}=3 \times \mathrm{Ce} /(2 \times \mathrm{La}+\mathrm{Pr})
$$

Note that all REE concentrations have been normalized to Post-Archean Australian Shale (PAAS) (Taylor and McLennan, 1985; McLennan, 2001).

\section{Results}

\subsection{Petrographic characteristics}

Forty-nine samples were examined petrographically in thin-sections under both natural and polarized light. The most common microfacies are intraclastic packstones, bioclastic packstones and wackestones, and radiolarian wackestones and mudstones. Two 
sources of carbonate material are present in the study sections: fine pelagic carbonate and coarse resedimented bioclastic-intraclastic carbonate shed from adjacent carbonate platforms (Fig. 7). The Pignola-Abriola section contains both pelagic and resedimented carbonate, with the latter consisting mainly of bioclasts and subordinately of carbonate intraclasts (Fig. 7a-bc). The Monte Volturino section also contains a mixture of carbonate types, although the resedimented material differs in character from that at Pignola-Abriola, consisting dominantly of intraclasts and extraclasts rather than bioclasts (Fig. 7d-e-f). The amount of pelagic carbonate is also lower at Monte Volturino than at Pignola-Abriola. The Madonna del Sirino section consists predominantly of fine pelagic carbonates (Fig. 7g-h). The petrographic differences among the study sections appear to reflect differences in proximity to carbonate shelf margins surrounding the Lagonegro Basin.

\subsection{Redox proxies}

The concentrations of molybdenum (Mo) and uranium (U) are low in all three study sections. Mo averages are just $2.0 \pm 2.5 \mathrm{ppm}$ at Pignola-Abriola, $0.25 \pm 0.3 \mathrm{ppm}$ at Monte Volturino, and $0.43 \pm 0.3 \mathrm{ppm}$ at Madonna del Sirino (Figs. 8-10). U concentrations are 0.2$11.2 \mathrm{ppm}$ with a mean of $2.2 \mathrm{ppm}$ at Pignola-Abriola, 0.1-0.8 ppm with a mean of $0.4 \mathrm{ppm}$ at Monte Volturino, and 0.1-1.7 ppm with a mean of 0.6 ppm at Madonna del Sirino (Figs. 8$10)$.

Total S average concentrations are low in the three study sections: $0.03 \%$ at PignolaAbriola, $0.02 \%$ at Monte Volturino, and $0.02 \%$ at Madonna del Sirino (Figs. 8-10). Molar $\mathrm{C}_{\text {org }}: \mathrm{P}$ ratios are quite constant among the study sections. $\mathrm{C}_{\text {org }}: \mathrm{P}$ ratios are 13-53 with a mean of 14 at Pignola-Abriola, 13-64 with a mean of 26 at Monte Volturino, and 5-70 with a mean of 28 at Madonna del Sirino (Figs. 8-10). $\mathrm{C}_{\text {org }}: \mathrm{P}$ ratios show no stratigraphic trends in the three study sections.

$\mathrm{Fe}_{\mathrm{T}} / \mathrm{Al}$ ratios are close to detrital background values (0.4-0.5; Lyons et al., 2003) at Pignola-Abriola. The other two sections show distinctly higher $\mathrm{Fe}_{\mathrm{T}} / \mathrm{Al}$ values: $0.8 \pm 0.3$ at Monte Volturino and up to 2.4 at Madonna del Sirino. Because there is so little sulfur in the study sections (average concentrations are $\leq 0.03 \%$, as noted above), this 'excess Fe' cannot be due to the addition of pyrite. Given that the most proximal section (Pignola-Abriola) shows normal background $\mathrm{Fe}_{\mathrm{T}} / \mathrm{Al}$ ratios, excess $\mathrm{Fe}$ is also unlikely to be related to influx of Fe-oxyhydroxides in the detrital fraction. 
$\mathrm{Ce} / \mathrm{Ce}^{*}$ ratios exhibit approximately the same range of values in all three study sections. $\mathrm{Ce} / \mathrm{Ce} *$ ratios are $0.65-1.28$ at Pignola-Abriola, 0.47-1.32 at Monte Volturino, and 0.54-1.58 at Madonna del Sirino. These are bulk-rock values and, given average Al concentrations ranging from $2.1 \%$ to $3.4 \%$ in the three study sections, it is likely that the REE fraction of most samples is derived mainly from detrital siliciclastics (e.g., clay minerals), making $\mathrm{Ce} / \mathrm{Ce}^{*}$ ratios valid as proxies for sediment provenance rather than watermass redox conditions.

\subsection{Productivity proxies}

Average total organic carbon (TOC) concentrations are $0.30 \pm 0.32 \%$ at PignolaAbriola with a peak of $1.0 \%, 0.10 \pm 0.03 \%$ at Monte Volturino, and $0.11 \pm 0.04 \%$ at Madonna del Sirino (Figs. 8-10). A second sample set from Pignola-Abriola consisting exclusively of units identified as black shales" in the field $(n=23)$ yielded only two samples having TOC $>1 \%$ (peak 1.5\%). All three sections show strong positive covariation of $\mathrm{Ba}$ and $\mathrm{Al}\left(\mathrm{r}^{2}=0.52\right.$, 0.58 , and 0.95 , respectively) with most samples plotting close to the inferred detrital $\mathrm{Ba} / \mathrm{Al}$ line. Thus, most samples contain exclusively detrital $\mathrm{Ba}$, and significant amounts of excess barium (>100 ppm) are present in only a few samples (Fig. 8-10). Biogenic silica concentrations range from $9.8 \%$ to $90.6 \%$ with a mean of $50 \%$ at Pignola-Abriola, from $4.3 \%$ to $78 \%$ with a mean of $47 \%$ at Monte Volturino, and from $3.5 \%$ to $95 \%$ with a mean of $73 \%$ at Madonna del Sirino (Figs. 8-10). All three sections exhibit a pronounced increase in biogenic silica through the NRB transition. Biogenic silica shows no significant correlation with TOC in any of the study sections $\left(\mathrm{r}^{2}<0.10\right)$, indicating a lack of relationship between these productivity proxies.

\subsection{Weathering proxies}

CIA* values are similar in the three study sections: $0.72-0.80$ with a mean of 0.75 at Pignola-Abriola, $0.62-0.82$ with a mean of 0.74 at Monte Volturino, and $0.68-0.84$ with a mean of 0.77 at Madonna del Sirino (Figs. 8-10). All three locales exhibit lower values at the base of the section and higher values at the top, with a gradual increase upsection through the Norian-Rhaetian transition interval. At Monte Volturino, two samples in the middle of the section exhibit values (0.62-0.63) that fall below the overall trend; these samples are from carbonate-rich beds $\left(>88 \% \mathrm{CaCO}_{3}\right)$ and thus likely to represent artifacts of lithologic variation. 


\section{Discussion}

\subsection{Redox conditions}

The depositional redox conditions of the study samples were evaluated using a combination of Mo and $\mathrm{U}$ concentrations and $\mathrm{C}_{\text {org }}: \mathrm{P}$ ratios. Mo and $\mathrm{U}$ are trace elements that have a strong affinity with euxinic depositional facies (Emerson and Huested, 1991; Algeo and Maynard, 2004; Calvert and Pedersen, 2007; Algeo and Tribovillard, 2009). They are present in low concentrations in plankton and detrital siliciclastics, so sedimentary enrichment is generally due to authigenic uptake of these elements from seawater at or close to the sediment-water interface. $\mathrm{U}$ enrichment begins in the suboxic zone (Fe(III)-Fe(II) boundary), where reduction from U(VI) to U(IV) yields relatively insoluble U-oxyhydroxides (Anderson, 1987; Todd et al., 1988; McKee and Todd, 1993; Zheng et al., 2002). In contrast, Mo enrichment requires the presence of relatively high levels of dissolved sulfide to facilitate formation of particle-reactive thiomolybdates (Helz et al., 1996). The uniformly low concentrations of Mo $(<8 \mathrm{ppm})$ and $U(<11 \mathrm{ppm})$ in all three study sections (Figs. 8-10) thus imply mainly oxic bottom waters, with perhaps a limited development of suboxic waters.

Sediment $\mathrm{C}_{\text {org }}: \mathrm{P}$ ratios provide paleoredox information due to differential rates of remineralization and preservation of organic carbon and phosphorus under oxic versus anoxic bottom waters. Living marine phytoplankton has a molar $\mathrm{C}_{\text {org }}: \mathrm{P}$ ratio of $\sim 106: 1$, i.e., the Redfield ratio (Redfield, 1958; Ho et al., 2003). In oxic depositional facies, $\mathrm{C}_{\text {org: }} \mathrm{P}$ ratios tend toward smaller values because remineralized organic carbon is lost whereas much remineralized phosphorus is retained in the sediment through adsorption onto $\mathrm{Fe}$ oxyhydroxides and formation of polyphosphates (Algeo and Ingall, 2007). In anoxic depositional facies, $\mathrm{C}_{\text {org }}: \mathrm{P}$ ratios tend toward larger values because organic matter decays slowly, yet labile phosphorus-bearing compounds are preferentially remineralized and the liberated P diffuses back into the overlying water column. Although a handful of samples in the study units yielded $\mathrm{C}_{\text {org }}: \mathrm{P}$ ratios $>100$, all of them have $\mathrm{P}$ concentrations $<0.02 \%$ and, thus, are regarded as artifacts because the uncertainty in $\mathrm{P}$ measurements is larger than the reported values. All samples with $\mathrm{P}$ concentrations $>0.02 \%$ yielded $\mathrm{C}_{\text {org }}: \mathrm{P}$ ratios $<100$, consistent with mainly oxic conditions in the study sections (Fig. 8-10). In summary, we infer mainly oxic deepwater conditions for the three study sections.

Black shales are present as thin interbeds at Pignola-Abriola (Fig. 4b; see Section 2.3). Rigo et al. (2015) documented a relationship between higher TOC and negative $\delta^{13} \mathrm{C}_{\text {org }}$ shifts 
within these shales, suggesting the repeated development of transiently anoxic conditions during the NRB transition at Pignola-Abriola. These black shales may represent the manifestation of widespread oceanic anoxia at the end of the Norian that has been documented previously at Williston Lake, British Columbia (Wignall et al., 2007), Kennecott Point, British Columbia (Ward et al., 2004), Ferguson Hill, Nevada (Ward et al., 2007), and Astartekløft, East Greenland (Hesselbo et al., 2002), but that was unknown in the western Tethyan region prior to the study of Rigo et al. (2015). That paper reported TOC concentrations of $>5 \%$ in these beds, but our re-analysis of the same sample set yielded only lower TOC concentrations ( $\leq 1.5 \%$; see Supplementary Information). As indicated by the redox proxies used in the present study, the deeper Lagonegro Basin (i.e., Monte Volturino and Madonna del Sirino) remained fully oxic throughout the NRB transition, and the shallower basin (i.e., Pignola-Abriola) was mostly oxic with possibly transient episodes of suboxic conditions.

\subsection{Marine productivity}

The paleoproductivity proxies used in this study include total organic carbon (TOC), excess $\mathrm{Ba}$, and biogenic $\mathrm{SiO}_{2}$. Sedimentary organic carbon content broadly correlates with productivity levels in many marine systems (Wefer et al., 1999), although the proportion of productivity that is preserved can depend strongly on sedimentation rates and redox conditions at the sediment-water interface (Canfield, 1994; Tyson, 2005; Schoepfer et al., 2014). TOC concentrations are mostly low in the study units, i.e., $<0.5 \%$ at Pignola-Abriola and $<0.2 \%$ at Monte Volturino and Madonna del Sirino, although rising to $>1 \%$ in the Upper Norian and NRB in the Pignola-Abriola section (Figs. 8-10). Low TOC concentrations may have been due to limited surface-water productivity and/or poor organic matter preservation (owing to mainly oxic deepwater conditions) in the Lagonegro Basin.

Excess barium $\left(\mathrm{Ba}_{\mathrm{xs}}\right)$ is a commonly used proxy to evaluate marine paleoproductivity, and it can exhibit a strong correlation with $\mathrm{C}_{\text {org }}$ fluxes in sediment-trap data (Dymond et al., 1992; François et al., 1995; Klump et al., 2000). Usually, the authigenic mineral barite is the carrier of $\mathrm{Ba}_{\mathrm{xs}}$, and it is commonly well-preserved (average $30 \%$ ) in well-oxygenated deepwater facies (Dehairs et al., 1987). However, biogenic barite tends to dissolve in anoxic facies (Torres et al., 1996), in which case $\mathrm{Ba}_{\mathrm{xs}}$ may severely underestimate bioproductivity (Eagle et al., 2003). In the three study sections, $\mathrm{Ba}_{\mathrm{xs}}$ values are low ( $<20$ ppm; Figs. 8-10), the only exceptions being some samples from mainly Pignola-Abriola section that yield modestly 
higher $\mathrm{Ba}_{\mathrm{xs}}$ values ( 200-300 ppm), and there is no correlation between $\mathrm{Ba}_{\mathrm{xs}}$ and TOC. These data are consistent with generally low bioproductivity in the Lagonegro Basin. The lack of evidence for reducing conditions (see Section 5.1) suggests that reductive loss of authigenic barite was not a cause of the low $\mathrm{Ba}_{\mathrm{xs}}$ concentrations.

Biogenic $\mathrm{SiO}_{2}$ concentrations are substantial in the three study sections, averaging 50\% at Pignola-Abriola, 39\% at Monte Volturino, and 62\% at Madonna del Sirino (Figs. 810), and all three sections show significant increases in $\mathrm{SiO}_{2(\text { bio })}$ upsection around the NRB. The lack of any evidence for a change in productivity rates during the NRB transition, as well as the lack of any relationship between $\mathrm{SiO}_{2(\text { bio) }}$ and $\mathrm{TOC}$ or $\mathrm{Ba}_{\mathrm{xs}}$, suggests that biosilica accumulation was not controlled primarily by bioproductivity. Thus, the most likely control on $\mathrm{SiO}_{2 \text { (bio) }}$ content was the degree of dilution by other sedimentary components (principally carbonate; see below).

In general, it is preferable to evaluate fluxes rather than concentrations of productivity proxies (cf. Schoepfer et al., 2014; Shen et al., 2014; Wei et al., 2014). The calculated average fluxes are $4.9 \mathrm{mg} \cdot \mathrm{cm}^{-2} \cdot \mathrm{kyr}^{-1}$ for organic carbon (OC), $637 \mathrm{mg} \cdot \mathrm{cm}^{-2} \cdot \mathrm{kyr}^{-1}$ for biogenic $\mathrm{SiO}_{2}(\mathrm{Sibio})$, and $287 \mathrm{mg} \cdot \mathrm{cm}^{-2} \cdot \mathrm{kyr}^{-1}$ for carbonates $\left(\mathrm{CaCO}_{3}\right)$ at Pignola-Abriola; $5.9 \mathrm{mg} \cdot \mathrm{cm}^{-}$ ${ }^{2} \cdot \mathrm{kyr}^{-1}$ for $\mathrm{OC}, 427 \mathrm{mg} \cdot \mathrm{cm}^{-2} \cdot \mathrm{kyr}^{-1}$ for Sibio, and $666 \mathrm{mg} \cdot \mathrm{cm}^{-2} \cdot \mathrm{kyr}^{-1}$ for $\mathrm{CaCO}_{3}$ at Monte Volturino; and $1.6 \mathrm{mg} \cdot \mathrm{cm}^{-2} \cdot \mathrm{kyr}^{-1}$ for OC, $620 \mathrm{mg} \cdot \mathrm{cm}^{-2} \cdot \mathrm{kyr}^{-1}$ for Sibio, and $118 \mathrm{mg} \cdot \mathrm{cm}^{-2} \cdot \mathrm{kyr}^{-1}$ for $\mathrm{CaCO}_{3}$ at Madonna del Sirino. The biosilica fluxes are more uniform than $\mathrm{CaCO}_{3}$, which vary strongly from sample to sample. This is probably because $\mathrm{CaCO}_{3}$ accumulation rates are heavily influenced by (1) episodic inputs of hemipelagic carbonate from adjacent shelf margins, and (2) possible vertical fluctuations in the CCD. The OC fluxes are lower than those for modern low-productivity systems such as the Pacific Warm Pool, the North Pacific subtropical/tropical gyres, and the Pan-Atlantic in which OC fluxes range from 25 to 39 $\mathrm{mmol} \mathrm{C} \cdot \mathrm{m}^{-1} \cdot \mathrm{yr}^{-1}$ (or 30.0 to $46.8 \mathrm{mg} \cdot \mathrm{cm}^{-2} \cdot \mathrm{kyr}^{-1}$ ) (Honjo et al., 2008). On the other hand, the biosilica fluxes in the study sections are within the range of typical values for moderately productive systems such as the North Atlantic Drift $\left(6.0 \mathrm{mmol} \mathrm{C} \cdot \mathrm{m}^{-1} \cdot \mathrm{yr}^{-1}\right.$ or $36.1 \mathrm{mg} \cdot \mathrm{cm}^{-2} \cdot \mathrm{kyr}^{-}$ $\left.{ }^{1}\right)$ and the Pacific Subarctic Gyre $\left(1118 \mathrm{mmol} \mathrm{C} \cdot \mathrm{m}^{-1} \cdot \mathrm{yr}^{-1}\right.$ or $6717 \mathrm{mg} \cdot \mathrm{cm}^{-2} \cdot \mathrm{kyr}^{-1}$ ) (Honjo et al., 2008).

\subsection{Chemical weathering fluxes}

The chemical index of alteration (CIA) is a widely used proxy for the intensity of terrestrial chemical weathering (Nesbitt and Young, 1982; 1989; Price and Velbel, 2003) that 
is sensitive to variations in humidity and land surface temperatures ( $\mathrm{Li}$ and Yang, 2010). The CIA* profiles of all three study sections show a relatively steady increase upsection, amounting to a difference of $\sim 0.10$ between the base and top of each section (Figs. $8-10$ ). The CIA* proxy rarely shows such a large increase, indicating that detrital siliciclastics (mainly clay minerals) entering the Lagonegro Basin were much more intensely weathered during middle Sevatian 2 than previously during the Early Norian. In the two sections containing the transition from the Calcari con Selce Fm. to the Scisti Silicei Fm. (i.e., Monte Volturino and Madonna del Sirino), a modest stepwise increase in CIA* values at the formation contact is evident. This pattern suggests that the change from carbonate to radiolarite sedimentation was connected with stronger chemical weathering within the basin's watershed.

This inference is consistent with other mineralogical and geochemical evidence for a major change in climate within the western Tethyan region around the Norian-Rhaetian boundary, e.g., higher concentrations of detrital elements (Amodeo, 1999; Di Leo et al., 2002) and the Al-rich, Ca-poor composition of red argillite beds in the Transitional Interval and the Scisti Silicei Fm. (Reggiani et al., 2005; Rigo et al., 2007). For parts of the western Tethyan region, it has been argued that more humid conditions led to enhanced siliciclastic sedimentation and reduced carbonate production, e.g., in the Southern Alps (Julian Alps, Bergamasc Alps, Hungary, Slovenia) (Berra, 2010; Berra et al., 2012). In the Lagonegro Basin, this change may have been recorded by the $\sim 3$-m-thick red shale at the base of the Scisti Silicei Formation (Fig. 4e).

Enhanced chemical weathering is commonly associated with more humid climate conditions (Raucsik and Varga, 2008; John et al., 2012). Warmer temperatures and greater climate humidity within the Lagonegro Basin began to develop during the Late Carnian Pluvial Event (Rigo et al., 2007) and intensified during the Late Norian. Increased precipitation and runoff into a silled basin is likely to generate a low-salinity surface layer and, hence, greater water-column stratification, as in the modern Black Sea (Murray, 1991), a condition that may be applicable to the more proximal and shallower areas of the Lagonegro Basin. Evidence for a global temperature rise during the NRB transition was recently published by Trotter et al. (2015). This temperature rise is likely to have been linked to preCAMP volcanism based on significant negative shifts in ${ }^{86} \mathrm{Sr} /{ }^{87} \mathrm{Sr}$ (Callegaro et al., 2012) and ${ }^{187} \mathrm{Os} /{ }^{188} \mathrm{Os}$ isotopic ratios (Kuroda et al., 2010). A concurrent decrease in $\delta^{13} \mathrm{C}_{\text {org }}$ along with an increase of TOC in various basins (see Section 5.1) reflect rising $p \mathrm{CO}_{2}$ prior to, and then peaking at, the NRB (Cleveland et al., 2008; Royer et al., 2007). 


\subsection{Depositional model for the Late Triassic Lagonegro Basin}

During the Late Triassic, synsedimentary tectonism was highly active in the Ionian Ocean due to rifting and spreading (Fig. 1) (Robertson et al., 1991; Ciarapica and Passeri, 1998; Finetti, 2003; Passeri et al., 2005). Although the Lagonegro Basin was connected to the larger Ionian Ocean, extensional tectonic activity may have resulted in half-graben formation and the development of one or more sills that restricted circulation within the deeper parts of the basin (Fig. 11). Differences in sedimentation among the study sections are consistent with each section having been located in a separate subbasin. First, the sections exhibit highly variable amounts of resedimented carbonates from the basin margins and pebbly mudstones possibly derived from uplifted blocks within the basin (Passeri et al., 2005). Second, each study section exhibits a distinctly different detrital $\mathrm{Ba} / \mathrm{Al}$ ratio (see Section 3), suggesting different sources of detrital material to each subbasin. Third, deposition of black shales is confined to the most proximal section (i.e., Pignola-Abriola; see Sections 5.1), suggesting differences in watermass structure between the study sections and, thus, the presence of sills separating the deep watermasses of several subbasins. This tectonic fragmentation was related to active extension of rifting southward into the Ionian Ocean beginning in the Permian and continuing throughout the Triassic (Ciarapica and Passeri, 2005; Schettino and Turco, 2011).

The overall water balance in the Lagonegro Basin was probably negative, with less runoff into the basin than evaporation from its surface layer, with the deficit made good through inflows from the Ionian Ocean. The circulation pattern in such a basin would have been 'lagoonal', with inward surface-water flows and outward deepwater flows (such as in the modern Mediterranean Sea) (Demaison and Moore, 1980). A negative water balance in the Lagonegro Basin appears likely given that: 1) its paleolatitude was $\sim 28^{\circ} \mathrm{N}$ (Maron et al., 2015), i.e., within the dry subtropics, and 2) young ocean basins tend to have uplifted margins, with few rivers draining into them (as for the modern Red Sea). The high carbonate and low TOC content of most Lagonegro Basin sediments is a typical lithologic pattern for such settings, which are characterized by high dissolved inorganic carbon (DIC; owing to evaporation) and low nutrient levels (owing to deepwater export). In this context, the numerous thin black shale beds present within the Upper Norian (upper Sevatian) to lower Rhaetian of the Pignola-Abriola section may represent a response to strengthened watercolumn stratification due to increased regional precipitation, which is consistent with CIA evidence for enhanced weathering of siliciclastics during Sevatian 2 (Figs. 8-10). 
The Lagonegro Basin accumulated large amounts of carbonate sediment during the Carnian and Norian, most of which was hemipelagic in origin. Several lines of evidence suggest that the lithologic transition from the Calcari con Selce Fm. to the Scisti Silicei Fm. was due not to a change in phytoplankton community composition but, rather, a change in carbonate burial flux. First, productivity proxies provide no evidence of changes in productivity levels during the NRB transition. Second, the transition from the Calcari con Selce Fm. to the Scisti Silicei Fm. was markedly diachronous at a basinal scale, with deeperwater sections (e.g., Monte Volturino and Madonna del Sirino) undergoing the transition earlier than shallower sections near the basin margins (e.g., Pignola-Abriola). This pattern is inconsistent with a control by surface-water productivity changes (e.g., increased biosilica production) because such a mechanism would have produced a synchronous change in sediment lithology across the basin. Rather, the diachronous nature of the transition reflects its origin in a long-term relative rise of the carbonate compensation depth (CCD), which affected deep-water areas earlier than shallow-water areas of the Lagonegro Basin. The most likely mechanism was a slow subsidence of the study sites below the CCD, which led to a loss of carbonate accumulation, higher sediment $\mathrm{SiO}_{2(\text { bio) }}$ content (but probably no change in biosilica accumulation rates), and, thus, the lithologic transition from the Calcari con Selce Fm. to the Scisti Silicei Fm. (Fig. 3). Subsidence of the Lagonegro Basin was ultimately linked to aging and cooling of Ionian Ocean crust within the western Tethyan region (Giordano et al., 2010, 2011; Rigo et al., 2012; see Section 2.1). Subdivision of the Lagonegro Basin into multiple subbasins (e.g., Fig. 11) may also have generated local variations in water depth and CCD elevation. In addition, the greater proximity of the Pignola-Abriola section to sources of hemipelagic carbonate on surrounding carbonate shelves (cf. Fig. 2) may have effected a local deepening of the CCD, sustaining carbonate sedimentation at that locale longer (Fig. 11).

\subsection{Modern analogs for the Late Triassic Lagonegro Basin}

Several modern semi-restricted marine basins in synrift tectonic settings may serve as analogs to the Late Triassic Lagonegro Basin, among which the best-studied are the Guaymas Basin and the Red Sea. The Guaymas Basin is a 2000-m-deep basin in the Gulf of California with relatively narrow shelves on either side that is geologically young (initiated ca. $5 \mathrm{Ma}$ ) (Bray, 1988). It is a site of active seafloor spreading as part of a complex rift zone that is transitional between the divergent boundary of the East Pacific Rise and the transform boundary of the San Andreas Fault (Koski et al., 1985; Robles and Marinone, 1987). High 
productivity and restricted deep waters result in substantial organic matter accumulation (TOC to 13\%) and locally reducing conditions (Peter and Shanks, 1992). Seawater salinities are persistently 1-2\%o higher than in the adjacent Pacific Ocean (Bray, 1988) and fluctuate seasonally in response to deepening and shallowing of the pycnocline (Robles and Marinone, 1987). The quantity of $\mathrm{SO}_{4}{ }^{2-}$ in bottom waters is near zero (Campbell and Gieskes, 1984), compared to $28 \mathrm{mM}$ for normal seawater. An important factor in generating significant anomalies in temperature, dissolved oxygen and dissolved silica in the basin bottom waters is hydrothermal activity. However, the hydrothermally influenced deposits are unusual in several respects: 1) absence of pyrite, 2) minor amounts of $\mathrm{Zn}$ sulfide and low combined ore metal content, and 3) abundance of non-sulfide phases (Koskiet al., 1985).

The Red Sea, a somewhat older rift system (initiated $\sim 15 \mathrm{Ma}$ ) occupies an elongate, escarpment-bounded depression that is 250 to $450 \mathrm{~km}$ wide, between the uplifted Arabian and African shields (Cochran, 1983). This basin presents elevated temperatures and salinities in the deep-watermass because of the presence of a brine pool in multiple deep subbasins (Danielsson et al., 1980). These brines are produced by dissolution of Miocene evaporite deposits laid down during early stages of spreading of the Red Sea (Shanks and Bischoff, 1977). The chemistry of this brine is characterized by a small amount of admixed seawater that is not greater than $5 \%$. The salinity of the brines reaches $262 \mathrm{~g} \mathrm{~kg}^{-1}$, and the mean concentration of Mo is $19.3 \mu \mathrm{g} \mathrm{kg}^{-1}$ (Danielsson et al., 1980). Lower $\mathrm{SO}_{4}{ }^{2-}$ concentrations are found in the hot brines compared to normal seawater, about $0.75 \mathrm{~g} \mathrm{~kg}^{-1}$ (Sheu, 1990).

The features that these basins share with the Late Triassic Lagonegro Basin are active tectonism, creating local subbasins separated by sills, resulting in local variation in deepwater chemistry and redox conditions. An important difference between these modern analogs is that the Guaymas Basin exhibits relatively high productivity (Peter and Shanks, 1992), whereas the Red Sea exhibits generally low productivity (Levanon-Spanier et al., 1979; Veldhuis et al., 1997). This contrast is related to water balance and circulation patterns: the Guaymas Basin is in a region with positive water balance, resulting in estuarine circulation (Marinone, 2003), whereas the Red Sea is in a region with negative water balance, resulting in lagoonal circulation (Siedler, 1969; Abu-Zied et al., 2011). As inferred above, the Late Triassic Lagonegro Basin experienced mainly negative water balances and lagoonal circulation.

\section{Conclusions}


Based on the geochemical evidence of this study supported with literature data, we propose a depositional model for the Norian-Rhaetian Lagonegro Basin that is marked by a complex bathymetry consisting of a series of half-grabens, resulting in local variation in water depths, watermass chemistry, and degree of deepwater restriction. Surface productivity was low and deep waters remained mostly oxic throughout the Norian-Rhaetian transition owing to a negative water balance and a lagoonal circulation pattern, which resulted in deepwater outflows and nutrient export. However, increasing humidity and weathering intensity within the watershed of the Lagonegro Basin during the early Rhaetian resulted in episodes of strengthened water-column stratification, improving preservation of organic matter as recorded by multiple thin black shales in the more proximal parts of the basin (e.g., Pignola-Abriola). A time-transgressive shift from carbonate sediments of the Calcari con Selce to biosiliceous sediments of the Scisti Silicei records a gradual relative rise in the CCD, affecting distal sections prior to proximal sections. The most likely cause of this relative CCD rise was long-term basin subsidence linked to aging and cooling of young oceanic crust in the adjacent Ionian Ocean. Lastly, this study was able to constrain the position of the NorianRhaetian boundary (NRB) in the Pignola-Abriola, Monte Volturino, and Madonna del Sirino study sections through a combination of biostratigraphic and chemostratigraphic data, providing a more secure stratigraphic framework for future studies of the Upper Triassic succession of the Lagonegro Basin.

\section{Acknowledgments}

Research by TJA is supported by the U.S. National Science Foundation (Sedimentary Geology and Paleobiology program), the NASA Exobiology program, and the China University of Geosciences-Wuhan (SKL-GPMR program GPMR201301, and SKL-BGEG program BGL201407). $\mathrm{MC}$ and AB research was supported by PRIN 2008 (2008BEF5Z7_004) for University of Perugia. MR research was supported by Faculty project funds CPDA152211/15 (University of Padua).

\section{References}

Abu-Zied, R.H., Bantan, R.A., El Mamoney, M.H., 2011. Present environmental status of the Shuaiba Lagoon, Red Sea Coast, Saudi Arabia. J King Abdulaziz University, Marine Science, 22(2), 159-179. DOI: 10.4197/Mar.22-2.9 
Algeo, T.J., Maynard, J.B., 2004. Trace-element behavior and redox facies in core shales of Upper Pennsylvanian Kansas-type cyclothems. Chemical Geology 206(3), 289-318. DOI: 10.1016/j.chemgeo.2003.12.009

Algeo, T.J., Ingall, E.D., 2007. Sedimentary $\mathrm{C}_{\text {org:P }} \mathrm{P}$ ratios, paleocean ventilation, and Phanerozoic atmospheric $\mathrm{pO}_{2}$. Palaeogeography, Palaeoclimatology, Palaeoecology 256(3), 130-155. doi: 10.1016/j.palaeo.2007.02.029

Algeo, T.J., Tribovillard, N., 2009. Environmental analysis of paleoceanographic systems based on molybdenum-uranium covariation. Chemical Geology 268(3), 211-225. doi: 10.1016/j.chemgeo.2009.09.001

Amodeo, F., Molisso, F., Kozur, H., Marsella, E., D’Argenio, B., 1993. Age of transitional beds from cherty limestone (Calcari con Selce) to radiolarites (Scisti Silicei) in the Lagonegro domain (southern Italy): First evidence of Rhaetian conodonts in peninsular Italy. Bollettino del Servizio Geologico Italiano 110, 3-22.

Amodeo, F., 1999. Il Triassico terminale - Giurassico del Bacino Lagonegrese. Studi stratigrafici sugli Scisti Silicei della Basilicata (Italia meridionale). Mémoires de Géologie (Université de Lausanne) 33, 160 pp. (in Italian).

Anderson, R.F., 1987. Redox behavior of uranium in an anoxic marine basin. Uranium 3(24), 145-164.

Bazzucchi, P., Bertinelli, A., Ciarapica, G., Marcucci, M., Passeri, L., Rigo, M., Roghi, G., 2005. The Late Triassic-Jurassic stratigraphic succession of Pignola-Abriola (Lagonegro-Molise Basin, Southern Apennines, Italy). Bollettino della Società Geologica Italiana 124(1), 143-153.

Berra, F., 2012. Sea-level fall, carbonate production, rainy days: How do they relate? Insight from Triassic carbonate platforms (Western Tethys, Southern Alps, Italy). Geology, 40(3), 271-274. DOI: 10.1130/G32803.1

Berra, F., Jadoul, F., Anelli, A., 2010. Environmental control on the end of the Dolomia Principale/Hauptdolomit depositional system in the central Alps: coupling sea-level and climate changes. Palaeogeography, Palaeoclimatology, Palaeoecology, 290(1), 138-150. DOI: 10.1016/j.palaeo.2009.06.037 
Bertinelli, A., Casacci, M., Concheri, G., Gattolin, G., Godfrey, L., Katz, M.E., Maron, M., Mazza, M., Mietto, P., Muttoni, G., Rigo, M., Sprovieri, M., Stellin, F., Zaffani, M. (In press). The Norian/Rhaetian boundary interval at Pignola-Abriola section (Southern Apennines, Italy) as a GSSP candidate for the Rhaetian Stage: an update. Albertiana, 43.

Bertinelli, A., Ciarapica, G., De Zanche, V., Marcucci, M., Mietto, P., Passeri, L., Rigo, M., Roghi, G., 2005a. Stratigraphic evolution of the Triassic-Jurassic Sasso di Castalda succession (Lagonegro Basin, Southern Apennines, Italy). Bollettino della Società Geologica Italiana 124, 161-175.

Bertinelli, A., Ciarapica, G., Passeri L., 2005b. Late Triassic-Jurassic basinal successions in Molise and northern Basilicata: the northernmost witness of the Lagonegro domain. Bollettino della Società Geologica Italiana 124, 177-188.

Böstrom, K., Peterson, M.N.A., Joensuu, O., Fisher, D.E., 1969. Aluminum-poor ferromanganoan sediments on active oceanic ridges. Journal of Geophysical Research 74(12), 3261-3270. DOI: 10.1029/JB074i012p03261

Bray, N.A., 1988. Thermohaline circulation in the Gulf of California. Journal of Geophysical Research 93(5), 4993-5020. DOI: 10.1029/JC093iC05p04993

Callegaro, S., Rigo, M., Chiaradia, M., Marzoli, A., 2012. Latest Triassic marine Sr isotopic variations, possible causes and implications. Terra Nova 24(2), 130-135. DOI: 10.1111/j.1365-3121.2011.01046.x

Calvert, S.E., Pedersen, T.F., 2007. Elemental proxies for palaeoclimatic and palaeoceanographic variability in marine sediments: Interpretation and application. In: Hillaire-Marcel, C., De Vernal, A. (Eds.), Proxies in Late Cenozoic Paleoceanography, Elsevier, Amsterdam, pp. 567-644. DOI: 10.1016/S15725480(07)01019-6

Campbell, A.C., Gieskes, J.M., 1984. Water column anomalies associated with hydrothermal activity in the Guaymas Basin, Gulf of California. Earth and Planetary Science Letters 68(1), 57-72. DOI: 10.1016/0012-821X(84)90140-7

Canfield, D.E., 1994. Factors influencing organic carbon preservation in marine sediments. Chemical Geology 114(3), 315-329. DOI: 10.1038/369455a0 
Carter, E.S., 1993. Biochronology and paleontology of uppermost Triassic (Rhaetian) radiolarians, Queen Charlotte Islands, British Columbia, Canada. Mémoires de Géologie (Lausanne) 11, 175 pp.

Ciarapica, G., Passeri, L., 1998. Evoluzione paleogeografica degli Appennini. Atti Ticinensi Scienze della Terra Pavia 40, 233-290 (in Italian).

Ciarapica, G., Passeri, L., 2000. Le facies del Triassico inferiore e medio (Fm. di Monte Facito Auctt.) nelle aree di Sasso di Castalda e di Moliterno (Basilicata). Bollettino della Società Geologica Italiana 119(2), 339-378 (in Italian).

Ciarapica, G., Passeri, L., 2002. The palaeogeographic duplicity of the Apennines. Bollettino della Società Geologica Italiana 121(1), 67-75.

Ciarapica, G., Passeri, L., 2005. Ionian Tethydes in the Southern Apennines. In: Finetti, I.R. (Ed.), CROP Project: Deep Seismic Exploration of the Central Mediterranean and Italy. Elsevier, Amsterdam, pp. 209-224.

Ciarapica, G., 2007. Regional and global changes around the Triassic-Jurassic boundary reflected in the late Norian - Hettangian history of the Apennine basins. Palaeogeography, Palaeoclimatology, Palaeoecology 244(1), 34-51. DOI: 10.1016/j.palaeo.2006.06.022

Cleveland, D.M., Nordt, L.C., Dworkin, S.I., Atchley, S.C., 2008. Pedogenic carbonate isotopes as evidence for extreme climatic events preceding the Triassic-Jurassic boundary: Implications for the biotic crisis?. Geological Society of America Bulletin, 120(11-12), 1408-1415. DOI: 10.1130/B26332.1

Cochran, J.R., 1983. A model for development of Red Sea. American Association of Petroleum Geologists Bulletin 67(1), 41-69.

Corrado, S., Aldega, L., Di Leo, P., Giampaolo, C., Invernizzi, C., Mazzoli, S., Zattin, M., 2005. Thermal maturity of the axial zone of the southern Apennines fold-and-thrust belt (Italy) from multiple organic and inorganic indicators. Terra Nova 17(1), 56-65.

Danielsson, L.G., Dyrssen, D., Granéli, A., 1980. Chemical investigations of Atlantis II and Discovery brines in the Red Sea. Geochimica et Cosmochimica Acta 44(12), 20512065. DOI: 10.1016/0016-7037(80)90203-3 
De Capoa Bonardi, P., 1984. Halobia zones in the pelagic Late Triassic sequences of the Central Mediterranean area (Greece, Yugoslavia, southern Apennines, Sicily). Bollettino della Società Paleontologica Italiana 23, 91-102.

Dehairs, F., Lambert, C.E., Chesselet, R., Risler, N., 1987. The biological production of marine suspended barite and the barium cycle in the Western Mediterranean Sea. Biogeochemistry 4(2), 119-140.

Demaison, G.J., Moore, G.T., 1980. Anoxic environments and oil source bed genesis. American Association of Petroleum Geologists Bulletin 64(8), 1179-1209.

Dewey, J.F., Pitman, W.C., Ryan, W.B., Bonnin, J., 1973. Plate tectonics and the evolution of the Alpine system. Geological Society of America Bulletin 84(10), 3137-3180. DOI: 10.1130/0016-7606(1973)84<3137:PTATEO>2.0.CO;2

Di Leo, P., Dinelli, E., Mongelli, G., Schiattarella, M., 2002. Geology and geochemistry of Jurassic pelagic sediments, Scisti Silicei Formation, southern Apennines, Italy. Sedimentary Geology 150(3), 229-246. DOI: 10.1016/S0037-0738(01)00181-6

Dymond, J., Suess, E., Lyle, M., 1992. Barium in deep-sea sediment: A geochemical proxy for paleoproductivity. Paleoceanography 7(2), 163-181. DOI: 10.1029/92PA01080

Eagle, M., Paytan, A., Arrigo, K.R., van Dijken, G., Murray, R.W., 2003. A comparison between excess barium and barite as indicators of carbon export. Paleoceanography 18(1), 1021. DOI: 10.1029/2002PA000793

Emerson, S.R., Huested, S.S., 1991. Ocean anoxia and the concentrations of molybdenum and vanadium in seawater. Marine Chemistry 34(3), 177-196. DOI:10.1016/03044203(91)90002-E

Epstein, A.G., Epstein, J.B., Harris, L.D., 1977. Conodont color alteration an index to organic metamorphism. U.S. Geological Survey Professional Paper 995, 27 pp.

Finetti, I.R., 1982. Structure, stratigraphy and evolution of central Mediterranean. Bollettino di Geofisica Teorica e Applicata 24, 247-315.

Finetti, I.R., 1985. Structure and evolution of the Central Mediterranean (Pelagian and Ionian Sea). In: Stanley, D.J., Wezel, F.C. (Eds.), Geological Evolution of the Mediterranean Basin. Springer-Verlag, New York, pp. 215-230. 
Finetti, I.R., 2003. Depositional basin and tectonodynamics of the "Ionides" (Lagonegrese units) from new CROP seismic data. In: Workshop "Late Triassic-Early Jurassic Events in the Framework of the Pangea Breakup", Field Trip Guidebook, Capri, Italy, pp. 36-37.

Finetti, I.R., 2004. Innovative CROP seismic highlight on the Mediterranean region. In: Crescenti, U., d'Offizi, S., Merlino, S., Sacchi, L. (Eds.), Geology of Italy. Volume speciale della Società Geologica Italiana, International Geological Congress 32, Florence, Italy, pp. 131-140.

Finetti, I.R. (Ed.), 2005. CROP Project, Deep Seismic Exploration of the Central Mediterranean and Italy, 2 vols. Elsevier, Amsterdam, 794 pp.

François, R., Honjo, S., Manganini, S.J., Ravizza, G.E., 1995. Biogenic barium fluxes to the deep sea: Implications for paleoproductivity reconstruction. Global Biogeochemical Cycles 9, 289-303. DOI: 10.1029/95GB00021

Giordano, N., Rigo, M., Ciarapica, G., Bertinelli, A., 2010. New biostratigraphical constraints for the Norian/Rhaetian boundary: data from Lagonegro Basin, Southern Apennines, Italy. Lethaia 43, 573-586. DOI: 10.1111/j.1502-3931.2010.00219.x

Giordano, N., Ciarapica, G., Bertinelli, A., Rigo, M., 2011. The Norian-Rhaetian interval in two sections of the Lagonegro area: the transition from carbonate to siliceous deposition. Bollettino della Società Geologica Italiana 130(3), 380-393. DOI: 10.3301/IJG.2011.11

Gradstein, F.M., Ogg, J.G., Schmitz, M., Ogg, G., 2012. The Geological Time Scale 2012. Elsevier, Amsterdam, 2 vols., 1142 pp.

Haq, B.U., Hardenbol, J., Vail, P.R., 1987. Chronology of fluctuating sea levels since the Triassic. Science 235(4793), 1156-1167.

Hartkopf-Fröder, C., Königshof, P., Littke, R., Schwarzbauer, J., 2015. Optical thermal maturity parameters and organic geochemical alteration at low grade diagenesis to anchimetamorphism: A review. International Journal of Coal Geology, 150, 74-119. DOI: 10.1016/j.coal.2015.06.005 
Helz, G.R., Miller, C.V., Charnock, J.M., Mosselmans, J.L.W., Pattrick, R.A.D., Garner, C.D., Vaughan, D.J., 1996. Mechanisms of molybdenum removal from the sea and its concentration in black shales: EXAFS evidences. Geochimica et Cosmochimica Acta 60, 3631-3642. DOI: 10.1016/0016-7037(96)00195-0

Hesselbo, S.P., Robinson, S.A., Surlyk, F., Piasecki, S., 2002. Terrestrial and marine extinction at the Triassic-Jurassic boundary synchronized with major carbon-cycle perturbation: A link to initiation of massive volcanism?. Geology, 30(3), 251-254. DOI: 10.1130/0091-7613(2002)030<0251:TAMEAT>2.0.CO;2

Ho, T.Y., Quigg, A., Finkel, Z.V., Milligan, A.J., Wyman, K., Falkowski, P.G., Morell, F.M.M., 2003. The elemental composition of some marine phytoplankton. Journal of Phycology 39, 1145-1159. DOI: 10.1111/j.0022-3646.2003.03-090.x

Honjo, S., Manganini, S.J., Krishfield, R.A., Francois, R., 2008. Particulate organic carbon fluxes to the ocean interior and factors controlling the biological pump: A synthesis of global sediment trap programs since 1983. Progress in Oceanography, 76(3), 217-285. DOI: $10.1016 /$ j.pocean.2007.11.003

Hunt, J.M., 1996. Petroleum Geochemistry and Geology, 2nd ed. W.H. Freeman, New York, 743 pp.

John, C.M., Banerjee, N.R., Longstaffe, F.J., Sica, C., Law, K.R., Zachos, J.C., 2012. Clay assemblage and oxygen isotopic constraints on the weathering response to the Paleocene-Eocene thermal maximum, east coast of North America. Geology 40(7), 591-594. DOI: 10.1130/G32785.1

Klump, J., Hebbeln, D., Wefer G., 2000. The impact of sediment provenance on bariumbased productivity estimates. Marine Geology 169, 259-271. DOI: 10.1016/S00253227(00)00092-X

Koski, R.A., Lonsdale, P.F., Shanks, W.C., Berndt, M.E., Howe, S.S., 1985. Mineralogy and geochemistry of a sediment-hosted hydrothermal sulfide deposit from the Southern Trough of Guaymas Basin, Gulf of California. Journal of Geophysical Research B90(8), 6695-6707. DOI: 10.1029/JB090iB08p06695 
Krystyn, L., 2010. Decision report on the defining event for the base of the Rhaetian stage. Albertiana, 38, 11-12.

Kuroda, J., Hori, R.S., Suzuki, K., Grocke, D.R., Ohkouchi, N., 2010. Marine osmium isotope record across the Triassic-Jurassic boundary from a Pacific pelagic site. Geology 38, 1095-1098. DOI: 10.1130/G31223.1

Le Roy, P., Piqué, A., 2001. Triassic-Liassic Western Moroccan synrift basins in relation to the Central Atlantic opening. Marine Geology 172(3), 359-381. DOI: 10.1016/S00253227(00)00130-4

Levanon-Spanier, I., Padan, E., Reiss, Z., 1979. Primary production in a desert-enclosed sea-the Gulf of Elat (Aqaba), Red Sea. Deep Sea Research Part A. Oceanographic Research Papers, 26(6), 673-685. DOI: 10.1016/0198-0149(79)90040-2

Li, C., Yang, S., 2010. Is chemical index of alteration (CIA) a reliable proxy for chemical weathering in global drainage basins? American Journal of Science 310, 111-127. DOI: $10.2475 / 02.2010 .03$

Lyons T.W., Werne J.P., Hollander D.J. and Murray R.W., 2003. Contrasting sulfur geochemistry and $\mathrm{Fe} / \mathrm{Al}$ and $\mathrm{Mo} / \mathrm{Al}$ ratios across the last oxic-to-anoxic transition in the Cariaco Basin, Venezuela. Chemical Geology 195, 131-157.

Marinone, S.G., 2003. A three-dimensional model of the mean and seasonal circulation of the Gulf of California. Journal of Geophysical Research, 108(C10), 3325. DOI: 10.1029/2002JC001720

Maron, M., Rigo, M., Bertinelli, A., Katz, M.E., Godfrey, L., Zaffani, M., Muttoni, G., 2015. Magnetostratigraphy, biostratigraphy and chemostratigraphy of the Pignola-Abriola section: new constraints for the Norian/Rhaetian boundary. Geological Society of America Bulletin, B31106-1. DOI: 10.1130/B31106.1.

Martin-Rojas, I., Somma, R., Delgado, F., Estévez, A., Iannace, A., Perrone, V., Zamparelli V., 2009. Triassic continental rifting of Pangaea: direct evidence from the Alpujarride carbonates, Betic Cordillera, SE Spain. Journal of the Geological Society of London 166(3), 447-458. DOI: 10.1144/0016-76492008-091 
McKee, B.A., Todd, J.F., 1993. Uranium behavior in a permanently anoxic fjord: Microbial control? Limnology and Oceanography 38, 408-414.

McLennan, S.M., 2001. Relationships between the trace element composition of sedimentary rocks and upper continental crust. Geochemistry Geophysics Geosystems 2(4). DOI: 10.1029/2000GC000109

Miconnet, P., 1983. La région de Lagonegro (Italie méridionale): évolution géologique d'un bassin dans son cadre alpin. Doctoral dissertation III cicle, Université des Sciences et Techniques de Lille, Lille, France, 185 pp. (in French).

Mongelli, G., 2004. Rare-earth elements in Oligo-Miocenic pelitic sediments from Lagonegro Basin, southern Apennines, Italy: implications for provenance and source area weathering. International Journal of Earth Science 93, 612-620.

Mostardini, F., Merlini, S., 1986. Appennino Centro Meridionale - Sezioni Geologiche e Proposta di Modello Strutturale. Memorie della Società Geologica Italiana 35, 177202 (in Italian).

Murray, J.W., 1991. Hydrographic variability in the Black Sea. In: Izdar, E., Murray, J.W. (Eds.) Black Sea Oceanography, Springer, New York, pp. 1-15.

Nesbitt, H.W., Young, G.M., 1982. Early Proterozoic climates and plate motions inferred from major element chemistry of lutites. Nature 299, 715-717.

Nesbitt, H.W., Young, G.M., 1984. Prediction of some weathering trends of plutonic and volcanic rocks based on thermodynamic and kinetic considerations. Geochimica et Cosmochimica Acta 48, 1523-1534. DOI: 10.1016/0016-7037(84)90408-3

Nesbitt, H.W., Young, G.M., 1989. Formation and diagenesis of weathering profiles. Journal of Geology 97, 129-147.

Ogg, J.G., 2012. Triassic. In: Gradstein, F.M, Ogg, J.G., Schmitz, M., Ogg, G. (Eds.), The Geologic Time Scale 2012, vol. 2, Elsevier, Amsterdam, pp. 681-730.

Passeri, L., Bertinelli, A., Ciarapica, G., 2005. Paleogeographic meaning of the late TriassicEarly Jurassic Lagonegro units. Bollettino della Società Geologica Italiana 124, 231245. 
Passeri, L., Ciarapica,G., 2010. Le litofacies permiane e triassiche della formazione di M. Facito auctt. nell'area di M. Facito (successione di Lagonegro, Appennino meridionale). Italian Journal of Geoscience 129(1), 29-50 (in Italian). DOI: 10.3301/IJG.2009.03

Peter, J.M., Shanks, W.C., III, 1992. Sulfur, carbon, and oxygen isotope variations in submarine hydrothermal deposits of Guaymas Basin, Gulf of California, USA. Geochimica et Cosmochimica Acta 56(5), 2025-2040. DOI: 10.1016/00167037(92)90327-F

Pollastro, R.M., 1993. Considerations and applications of the illite/smectite geothermometer in hydrocarbon-bearing rocks of Miocene to Mississippian age. Clays and Clay Minerals, 41, 119-133.

Preto, N., Rigo,M., Agnini, C., Bertinelli, A., Guaiumi, C., Borello, S., Westphal, H., 2012. Triassic and Jurassic calcareous nannofossils of the Pizzo Mondello section: a SEM study. Rivista Italiana di Paleontologia e Stratigrafia 118(1), 134-141.

Preto, N., Agnini, C., Rigo, M., Westphal, H., 2013. The calcareous nannofossil Prinsiosphera achieved rock-forming abundances in the latest Triassic of western Tethys: consequences for the $\delta^{13} \mathrm{C}$ of bulk carbonate. Biogeosciences 10(9), 60536068. DOI: $10.5194 /$ bg-10-6053-2013

Price, J.R., Velbel, M.A., 2003. Chemical weathering indices applied to weathering profiles developed on heterogeneous felsic metamorphic parent rocks. Chemical Geology 202(3), 397-416. DOI: 10.1016/j.chemgeo.2002.11.001

Raucsik, B., Varga, A., 2008. Climato-environmental controls on clay mineralogy of the Hettangian-Bajocian successions of the Mecsek Mountains, Hungary: an evidence for extreme continental weathering during the early Toarcian oceanic anoxic event. Palaeogeography, Palaeoclimatology, Palaeoecology 265(1), 1-13. DOI: 10.1016/j.palaeo.2008.02.004

Redfield, A.C., 1958. The biological control of chemical factors in the environment. American Scientist 46, 205-222.

Reggiani, L., Bertinelli, A., Ciarapica, G., Marcucci, M., Passeri, L., Ricci, C., Rigo, M., 2005. Triassic-Jurassic stratigraphy of the Madonna del Sirino succession (Lagonegro 
Basin, Southern Apennines, Italy). Bollettino della Società Geologica Italiana 124, 281-291.

Rigo, M., De Zanche, V., Mietto, P., Preto, N., Roghi, G., 2005. Biostratigraphy of the Calcari con Selce formation. Bollettino della Società Geologica Italiana 124, 293-300.

Rigo, M., Preto, N., Roghi, G., Tateo, F., Mietto, P., 2007. A rise in the Carbonate Compensation Depth of western Tethys in the Carnian (Late Triassic): Deep-water evidence for the Carnian Pluvial Event. Palaeogeography, Palaeoclimatology, Palaeoecology 246, 188-205. DOI: 10.1016/j.palaeo.2006.09.013

Rigo, M., Joachimski, M.M., 2010. Palaeoecology of Late Triassic conodonts: Constraints from oxygen isotopes in biogenic apatite. Acta Palaentologica Polonica 55(3), 471478. DOI: http://dx.doi.org/10.4202/app.2009.0100

Rigo, M., Trotter, J.A., Preto, N., Williams, I.S., 2012. Oxygen isotopic evidence for Late Triassic monsoonal upwelling in the northwestern Tethys. Geology 40(6), 515-518. DOI: $10.1130 / \mathrm{G} 32792.1$

Rigo, M., Bertinelli, A., Concheri, G., Gattolin, G., Godfrey, L., Katz, M., Maron, M., Muttoni, G., Sprovieri, M., Stellin, F., Zaffani, M., 2015. The Pignola-Abriola section: a new GSSP candidate for the base of the Rhaetian Stage. Lethaia, DOI: 10.1111/let.12145.

Robertson, A.H.F., Clift, P.D., Degnan, P., Jones, G., 1991. Palaeogeographic and palaeotectonic evolution of the Eastern Mediterranean Neotethys. Palaeogeography, Palaeoclimatology, Palaeoecology $\quad 87(1-4), \quad 289-343 . \quad$ DOI: $\quad 10.1016 / 0031-$ 0182(91)90140-M

Robles, J.M., Marinone, S.G., 1987. Seasonal and interannual thermohaline variability in the Guaymas Basin of the Gulf of California. Continental Shelf Research 7(7), 715-733.

Royer, D.L., Berner, R.A., Park, J., 2007. Climate sensitivity constrained by CO2 concentrations over the past 420 million years. Nature 446(7135), 530-532. DOI: 10.1038/nature05699

Sadler, P.M., 1981. Sediment accumulation rates and the completeness of stratigraphic sections. Journal of Geology 89(5), 569-584. 
Scandone, P., 1967. Studi di geologia lucana: la serie calcareo-silico-marnosa ed i suoi rapporti con l'Appennino calcareo. Bollettino della Società dei Naturalisti in Napoli 76(2), 301-469 (in Italian).

Scandone, P., 1972. Studi di geologia lucana: nota illustrativa della carta dei terreni della serie calcareo-silico-marnosa. Bollettino della Società dei Naturalisti in Napoli 81, 225-300 (in Italian).

Scandone, P., 1975. Triassic seaways and the Jurassic Tethys Ocean in the central Mediterranean area. Nature 256, 117-119.

Schettino, A., Turco, E., 2009. Breakup of Pangaea and plate kinematics of the central Atlantic and Atlas regions. Geophysical Journal International 178(2), 1078-1097. DOI: 10.1111/j.1365-246X.2009.04186.x

Schettino, A., Turco, E., 2011. Tectonic history of the western Tethys since the Late Triassic. Geological Society of America Bulletin 123(1-2), 89-105. DOI: 10.1130/B30064.1

Schlische, R.W., Withjack, M.O., Olsen, P.E., 2003. Relative timing of CAMP, rifting, continental breakup, and basin inversion: tectonic significance. In: Hames, W., McHone, J.G., Renne, P., Ruppel, C. (Eds.), The Central Atlantic Magmatic Province: Insights from Fragments of Pangea. American Geophysical Union, Geophysical Monograph Series 136, pp. 33-59.

Schoepfer, S.D., Shen, J., Wei, H., Tyson, R.V., Ingall, E., Algeo, T.J., 2014. Total organic carbon, organic $\mathrm{P}$, and biogenic $\mathrm{Ba}$ accumulation rates as proxies for marine primary productivity and export flux. Earth-Science Reviews. DOI: 10.1016/j.earscirev.2014.08.017

Scrocca, D., 2010. Southern Apennines: structural setting and tectonic evolution. Journal of the Virtual Explorer 36(13), 1-24.

Selli, R., 1962. Il Paleogene nel quadro della geologia dell'Italia Meridionale. Memorie della Società Geologica Italiana 3, 737-789 (in Italian).

Shanks, W.C., III, Bischoff, J.L., 1977. Ore transport and deposition in the Red Sea geothermal system: a geochemical model. Geochimica et Cosmochimica Acta 41(10), 1507-1519. DOI: 10.1016/0016-7037(77)90255-1 
Shen, J., Schoepfer, S.D., Feng, Q.L., Zhou, L., Yu, J., Song, H.Y., Wei, H.Y., Algeo, T.J., 2014. Marine productivity changes during the Permian-Triassic boundary crisis and Early Triassic recovery. Earth-Science Reviews. DOI: 10.1016/j.earscirev.2014.11.002

Sheu, D.D., 1990. The anoxic Orca Basin (Gulf of Mexico) geochemistry of brines and sediments. Reviews in Aquatic Sciences 2(3-4), 491-507.

Siedler, G., 1969. General circulation of water masses in the Red Sea. Springer Berlin Heidelberg, 131-137.

Stampfli, G.M., Marcoux, J., Baud, A., 1991. Tethyan margins in space and time. Palaeogeography, Palaeoclimatology, Palaeoecology 87, 373-409. DOI: 10.1016/0031-0182(91)90142-E

Stampfli, G.M., Borel, G.D., 2002. A plate tectonic model for the Paleozoic and Mesozoic constrained by dynamic plate boundaries and restored synthetic oceanic isochrons. Earth and Planetary Science Letters 196, 17-33. DOI: 10.1016/S0012$821 \mathrm{X}(01) 00588-\mathrm{X}$

Tanner, L., Schiattarella, M., Di Leo, P., 2006. Carbon isotope record of Upper Triassic strata of the Lagonegro Basin, Southern Apennines, Italy: Preliminary results. In: Harris, J.D., Lucas, S.G., Spielmann, J.A., Lockley, M.G., Milner, A.R.C., Kirkland, J.I. (Eds.), The Triassic-Jurassic Terrestrial Transition. New Mexico Museum of Natural History and Science Bulletin 37, 23-28.

Taylor, S.R., McLennan, S.M. (1985). The Continental Crust: Its Composition and Evolution. Blackwell, Oxford, $312 \mathrm{pp}$.

Todd, J.F., Elsinger, R.J., Moore, W.S., 1988. The distributions of uranium, radium and thorium isotopes in two anoxic fjords; Framvaren Fjord (Norway) and Saanich Inlet (British Columbia). Marine Chemistry 23, 393-415. DOI: 10.1016/03044203(88)90107-7

Torres, M.E., Brumsack, H.J., Bohrmann, G., Emeis, K.C., 1996. Barite fronts in continental margin sediments: A new look at barium remobilization in the zone of sulfate reduction and formation of heavy barites in diagenetic fronts. Chemical Geology 127(1), 125-139. DOI: 10.1016/0009-2541(95)00090-9 
Trotter, A.J., Williams, S.I., Nicora, A., Mazza, M., Rigo, M, 2015. Long-term cycles of Triassic climate change: a new $\delta^{18} \mathrm{O}$ record from conodont apatite. Earth and Planetary Science Letters 415, 165-174. DOI: 10.1016/j.eps1.2015.01.038

Tyson, R.V., 2005. The" productivity versus preservation" controversy: cause, flaws, and resolution. Special Publication-Society for Sedimentary Geology (SEPM), 82, 17-33.

Veldhuis, M.J., Kraay, G.W., Van Bleijswijk, J.D., Baars, M.A., 1997. Seasonal and spatial variability in phytoplankton biomass, productivity and growth in the northwestern Indian Ocean: the southwest and northeast monsoon, 1992-1993. Deep Sea Research Part I: Oceanographic Research Papers, 44(3), 425-449. DOI: 10.1016/S09670637(96)00116-1

Ward, P.D., Garrison, G.H., Haggart, J.W., Kring, D.A., Beattie, M.J., 2004. Isotopic evidence bearing on Late Triassic extinction events, Queen Charlotte Islands, British Columbia, and implications for the duration and cause of the Triassic/Jurassic mass extinction. Earth and Planetary Science Letters, 224(3), 589-600. DOI: 10.1016/j.eps1.2004.04.034

Ward, P.D., Garrison, G.H., Williford, K.H., Kring, D.A., Goodwin, D., Beattie, M.J., McRoberts, C.A., 2007. The organic carbon isotopic and paleontological record across the Triassic-Jurassic boundary at the candidate GSSP section at Ferguson Hill, Muller Canyon, Nevada, USA. Palaeogeography, Palaeoclimatology, Palaeoecology, 244(1), 281-289. DOI: 10.1016/j.palaeo.2006.06.042

Wefer, G., Berger, W.H., Bijma, J., Fischer, G., 1999. Clues to ocean history: a brief overview of proxies. In: Fischer, G., Wefer, G. (Eds.), Use of Proxies in Paleoceanography. Springer, Berlin, pp. 1-68. DOI: 10.1007/978-3-642-58646-0_1

Wei, H.Y., Shen, J., Schoepfer, S.D., Krystyn, L., Richoz, S., Algeo, T.J., 2014. Environmental controls on marine ecosystem recovery following mass extinctions, with an example from the Early Triassic. Earth-Science Reviews 149, 104-131. DOI: 10.1016/j.earscirev.2014.10.007

Wignall, P.B., Zonneveld, J.P., Newton, R.J., Amor, K., Sephton, M. A., Hartley, S., 2007. The end Triassic mass extinction record of Williston Lake, British Columbia. 
Palaeogeography, Palaeoclimatology, Palaeoecology, 253(3), 385-406. DOI: 10.1016/j.palaeo.2007.06.020

Wotzlaw, J.F., Guex, J., Bartolini, A., Gallet, Y., Krystyn, L., McRoberts, C.A., Taylor, D., Schoene, B., Schaltegger, U., 2014. Towards accurate numerical calibration of the Late Triassic: High-precision U-Pb geochronology constraints on the duration of the Rhaetian. Geology, 42(7), 571-574. DOI: 10.1130/G35612.1

Young, G.M., Nesbitt, H.W., 1998. Processes controlling the distribution of $\mathrm{Ti}$ and $\mathrm{Al}$ in weathering profiles, siliciclastic sediments and sedimentary rocks. Journal of Sedimentary Research 68(3), 448-455.

Zheng, Y., Anderson, R.F., van Geen, A., Fleischer, M.Q., 2002. Preservation of particulate non-lithogenic uranium in marine sediments. Geochimica et Cosmochimica Acta 66, 3085-3092. DOI: 10.1016/S0016-7037(01)00632-9 


\section{Figure captions}

Figure 1. Paleogeographic map of the western Tethyan region during the Late Norian. The yellow star indicates the study area in the Lagonegro Basin (LB). The dashed line between Africa and Eurasia represents the rift segment connected to opening of the future Central Atlantic. Other tectonic features: A - Apulia, Ap-Apennine carbonate platform, B - Bosnian pelagic trough, Do - Dobrogea, Kp - Korapi Pelagonian crystalline zone, Ku - Kure, L - Lombardy, LSB - La Spezia Basin, Me-Ma-Va Maliac-Meliata-Vardar Ocean, Pi - Pindos, Scy - Scythian Platform, Ta - Taurides. Eq Equator.

Figure 2. (a) Geological map (modified from Ciarapica, 2007). The red dashed line shows the minimum area of the Lagonegro Basin, based on present-day exposures. (b) Inferred cross-section of the Lagonegro Basin during the Late Norian-early Rhaetian with approximate locations of the three study sections. The depth of the CCD is uncertain probably fluctuated but generally rose through time; the figure shows its position during the Late Norian to early Rhaetian (Giordano et al., 2011).

Figure 3. Stratigraphic units of Upper Triassic to Upper Jurassic age in the Lagonegro Basin. The diagram shows proximal to distal variation in lithologies and the approximate positions of the Pignola-Abriola (1), Monte Volturino (2), and Madonna del Sirino (3) sections. Note that the study interval corresponds to a major sea-level rise within the Lagonegro Basin but to a shallowing global sea-level (eustatic curve from Haq et al., 1987 ; local curve is original to this study).

Figure 4. Field photos. Pignola-Abriola section: (a) cherty limestone with intercalated dark shales, and (b) thick calcarenite beds and black-colored shales layers of the Calcari con Selce Fm. Monte Volturino section: (c) red argillites at the base of the Transitional Interval, and (d) soft-sediment deformation associated with slumping of limestone layers. Madonna del Sirino section: (e) black and red radiolarites and red argillites of the Scisti Silicei Fm., and (f) red argillites at the base of the Transitional Interval. 
Figure 5. Correlations of the three study sections. The correlations based on conodont biostratigraphy, chemostratigraphy, and radiolarian biozonation are shown by black lines, blue lines, and a grey-striped zone, respectively (see Section 2.4); the red lines indicate the new position of the NRB constrained by chemostratigraphic tie points (see Figure 6). Sources of biostratigraphic data: Pignola-Abriola - Bazzucchi et al. (2005) and Rigo et al. (2005, 2007); Monte Volturino - Giordano et al. (2010, 2011); Madonna del Sirino - Reggiani et al. (2005). C.S. - Calcari con Selce Fm.

Figure 6. Ce/Ce* profiles for the three study sections. Samples are plotted in correct stratigraphic order in the profiles, but the vertical spacing of samples has been adjusted to show the correspondence among sections of specific features (arrows) for each proxy. These features were used to refine correlations among the three study sections (Figure 5).

Figure 7. Thin sections plate. (a-b-c) are from Pignola-Abriola, (d-e-f) are from Monte Volturino, and (g-h) from Madonna del Sirino. (a) Halobia packstone (sample PA6). (b) Wackestone with radiolarians and spicules re-crystallized as calcite (sample PA27). (c) Intraclastic packstone, some microstylolites (sample PA15). (d) Volcanic clast-bearing calcarenite or intraclastic-extraclastic packstone (sample MV29). (e) Volcanic clastbearing calcarenite or intraclastic-extraclastic wackestone with radiolarians (sample MV32). (f) Skeletal wackestone with pyritized radiolarians, microstylolites (sample MV37). (g) Grumulous mudstone with few radiolarians; many microstylolites; high clay content (sample MSSS27). (h) Mudstone with oxidized microstylolites (sample MS51a).

Figure 8. Chemostratigraphy of the Pignola-Abriola section including redox proxies (Mo, U,

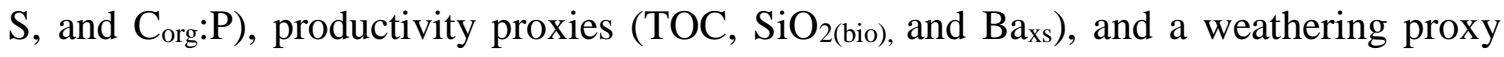
(CIA). BS = black shale units.

Figure 9. Chemostratigraphy of the Monte Volturino section. C.S. = Calcari con Selce; other details as in Figure 8. 
Figure 10. Chemostratigraphy of the Madonna del Sirino section. C.S. = Calcari con Selce; other details as in Figure 8.

Figure 11. Interpretative depositional model for the Lagonegro Basin during the late Norian to early Rhaetian. Red arrows represent the study sections: 1 = Pignola-Abriola, 2 = Monte Volturino, and 3 = Madonna del Sirino. Seafloor bathymetry is interpretative and intended to explain differences in sediment chemistry between the study sections. The distance of the sections from the platform margin is based on the frequency of resedimented carbonates (see Section 5.5 for details). Horizontal scale is approximate and inferred from Scrocca (2010); the CCD depth is local of the Lagonegro Basin only, and inferred from the study of Giordano et al. (2010). 


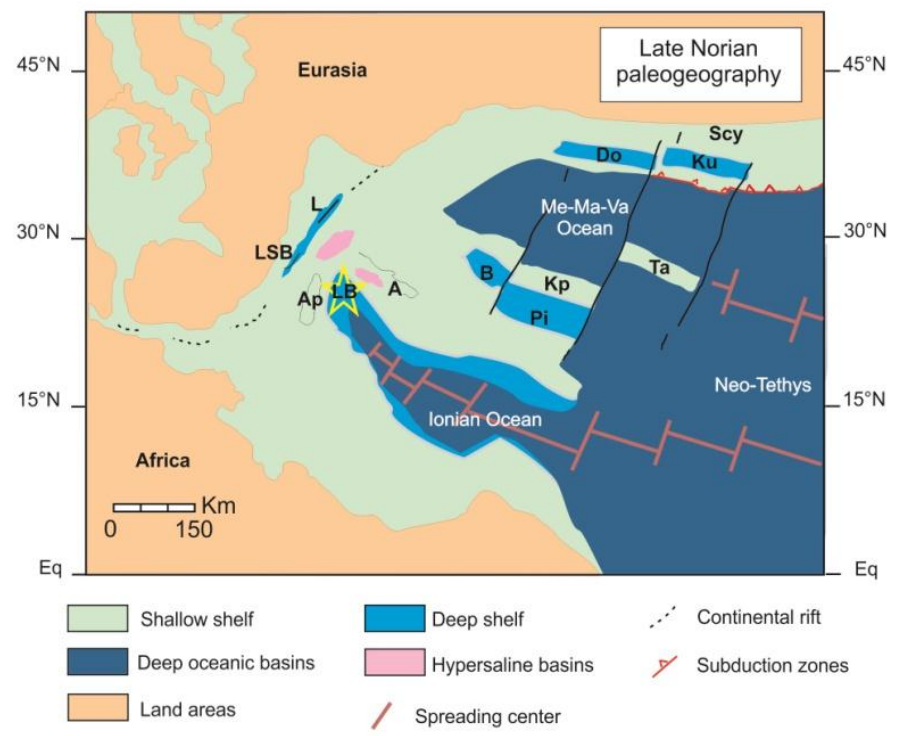

Figure 1. Paleogeographic map of the western Tethyan region during the Late Norian. The yellow star indicates the study area in the Lagonegro Basin (LB). The dashed line between Africa and Eurasia represents the rift segment connected to opening of the future Central Atlantic. Other tectonic features: A - Apulia, Ap-Apennine carbonate platform, B - Bosnian pelagic trough, Do - Dobrogea, Kp - Korapi Pelagonian crystalline zone, Ku - Kure, L - Lombardy, LSB - La Spezia Basin, Me-Ma-Va Maliac-Meliata-Vardar Ocean, Pi - Pindos, Scy - Scythian Platform, Ta - Taurides. Eq Equator. 


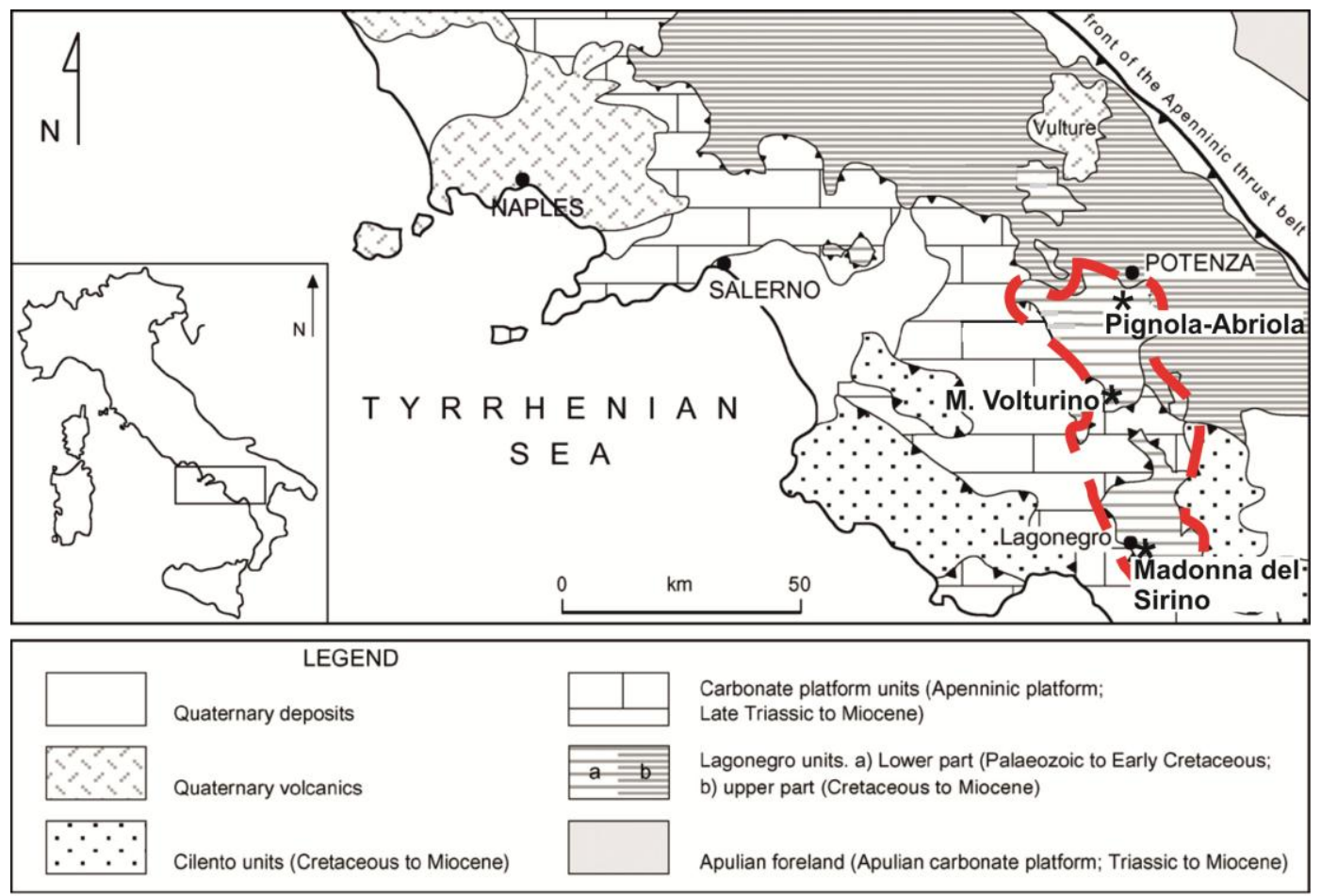

a

proximal

Pignola-Abriola

\section{distal}

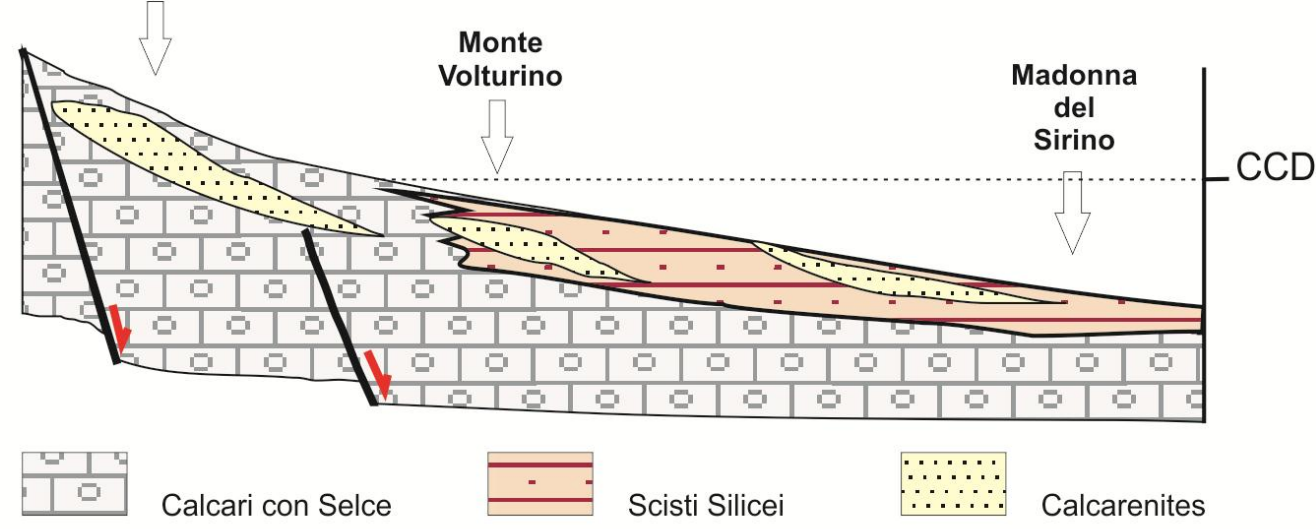

Figure 2. (a) Geological map (modified from Ciarapica, 2007). The red dashed line shows the minimum area of the Lagonegro Basin, based on present-day exposures. (b) Inferred cross-section of the Lagonegro Basin during the Late Norian-early Rhaetian with approximate locations of the three study sections. The depth of the CCD is uncertain probably fluctuated but generally rose through time; the figure shows its position during the Late Norian to early Rhaetian (Giordano et al., 2011). 


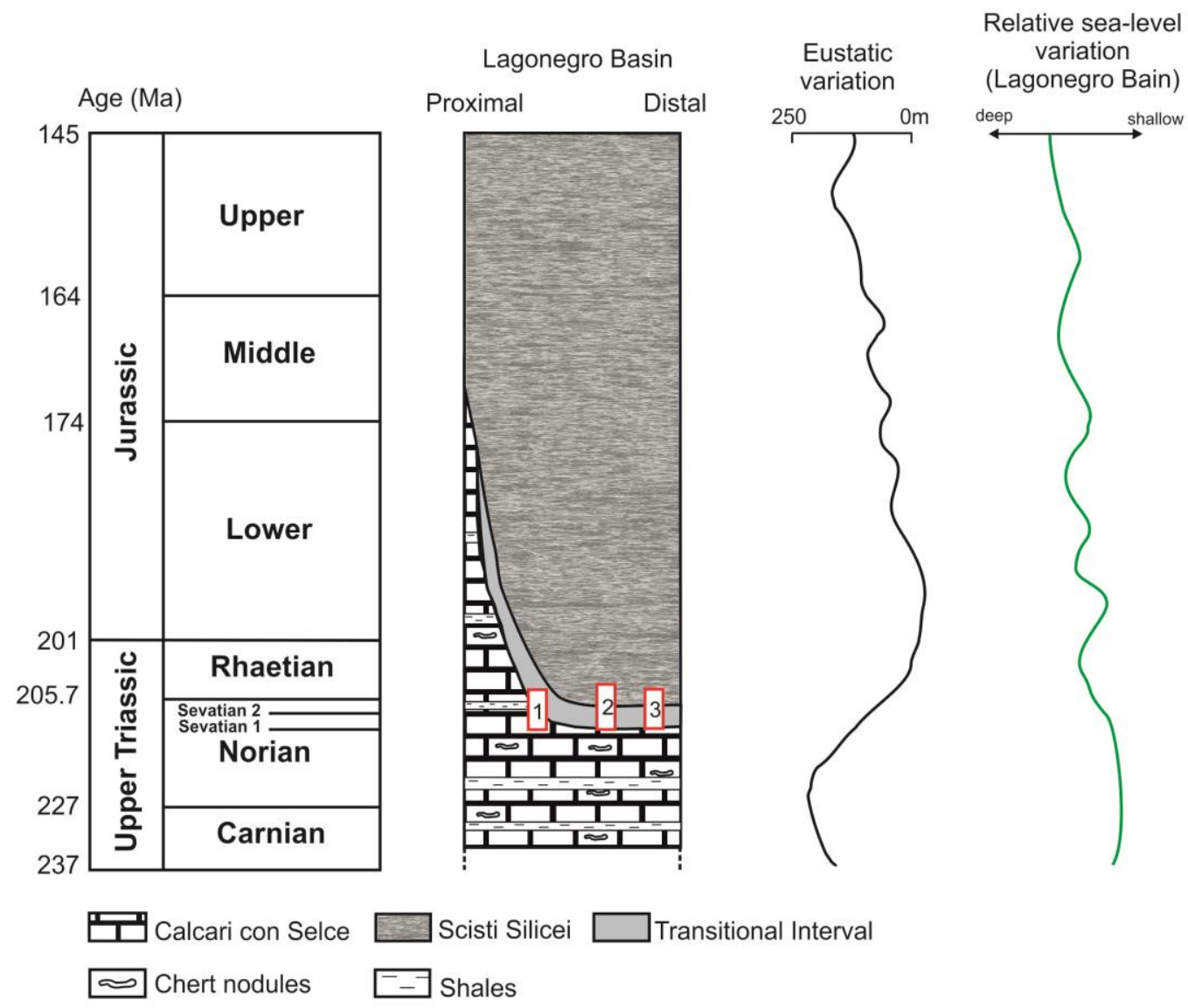

Figure 3. Stratigraphic units of Upper Triassic to Upper Jurassic age in the Lagonegro Basin. The diagram shows proximal to distal variation in lithologies and the approximate positions of the Pignola-Abriola (1), Monte Volturino (2), and Madonna del Sirino (3) sections. Note that the study interval corresponds to a major sea-level rise within the Lagonegro Basin but to a shallowing global sea-level (eustatic curve from Haq et al., 1987; local curve is original to this study). 

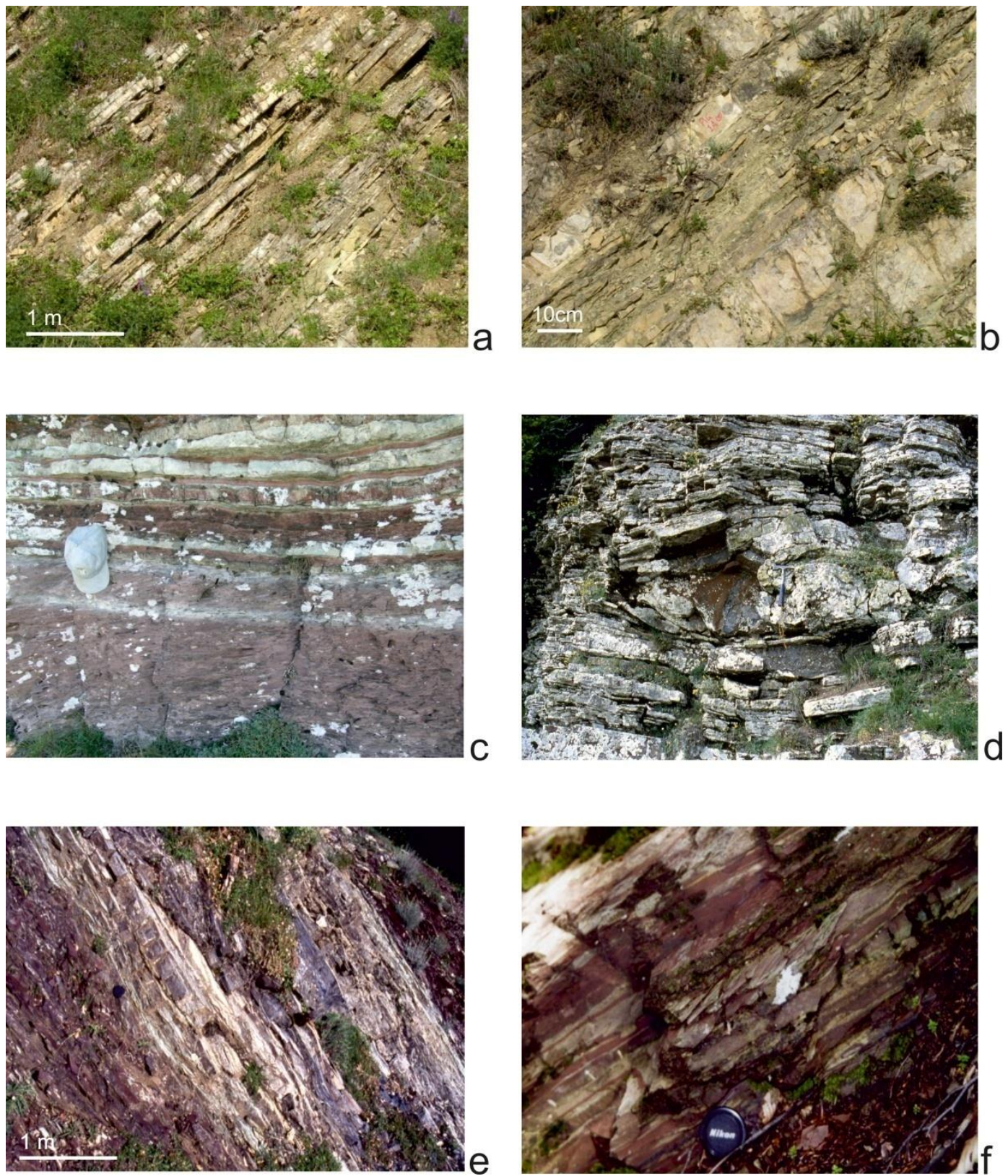

Figure 4. Field photos. Pignola-Abriola section: (a) cherty limestone with intercalated dark shales, and (b) thick calcarenite beds and black-colored shales layers of the Calcari con Selce Fm. Monte Volturino section: (c) red argillites at the base of the Transitional Interval, and (d) soft-sediment deformation associated with slumping of limestone layers. Madonna del Sirino section: (e) black and red radiolarites and red argillites of the Scisti Silicei Fm., and (f) red argillites at the base of the Transitional Interval. 
Figure

5.

Correlations

of the three

study

sections. The

correlations

based on

conodont

biostratigrap

hy,

chemostratig

raphy, and

radiolarian

biozonation

are shown by

black lines,

blue lines,

and a grey-

striped zone,

respectively

(see Section

2.4); the red

lines indicate

the new

position of

the NRB

constrained

by

chemostratig

raphic tie

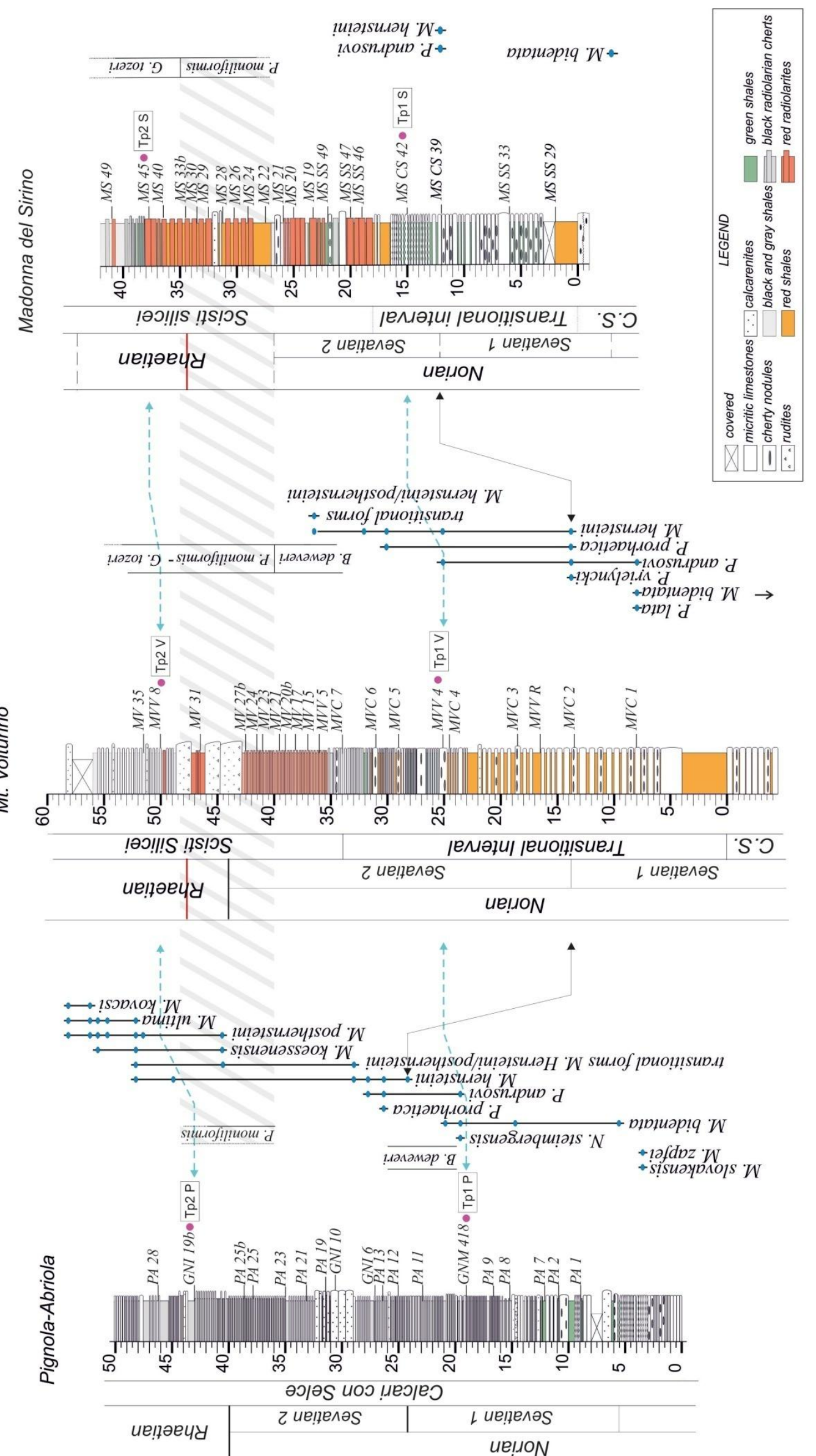


points (see Figure 6). Sources of biostratigraphic data: Pignola-Abriola - Bazzucchi et al. (2005) and Rigo et al. (2005, 2007); Monte Volturino - Giordano et al. (2010, 2011); Madonna del Sirino - Reggiani et al. (2005). C.S. - Calcari con Selce Fm.

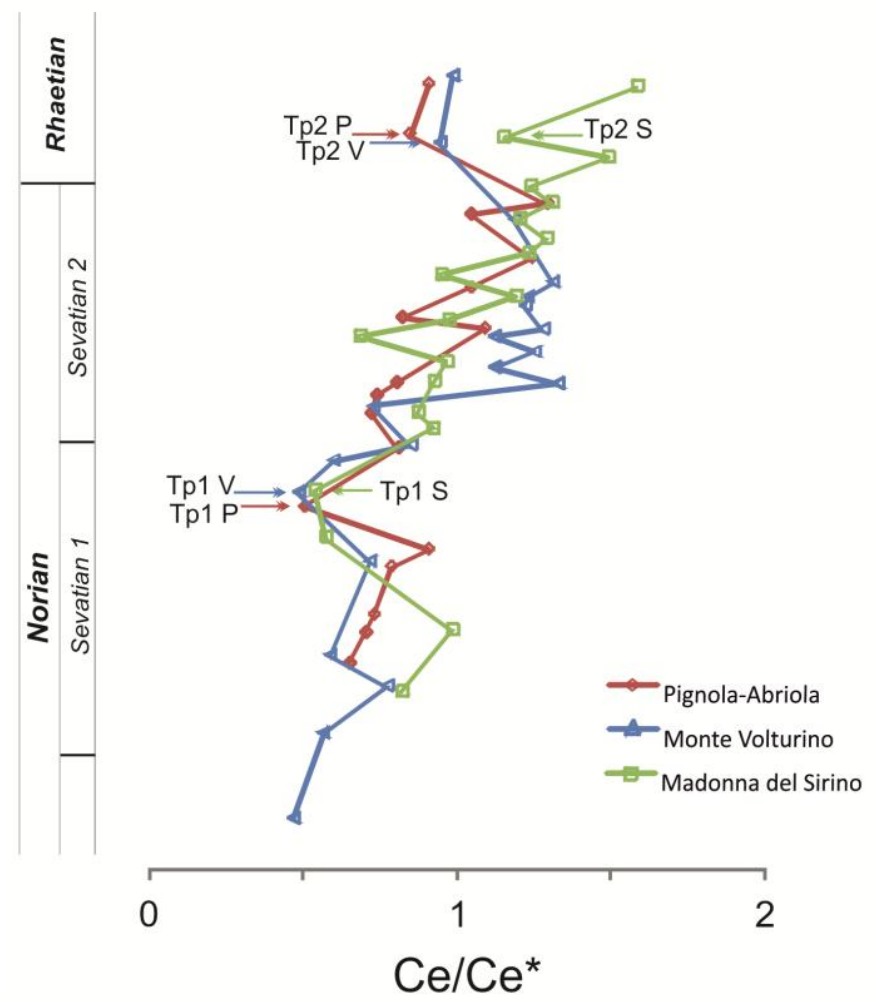

Figure 6. Ce/Ce* profiles for the three study sections. Samples are plotted in correct stratigraphic order in the profiles, but the vertical spacing of samples has been adjusted to show the correspondence among sections of specific features (arrows) for each proxy. These features were used to refine correlations among the three study sections (Figure 5). 

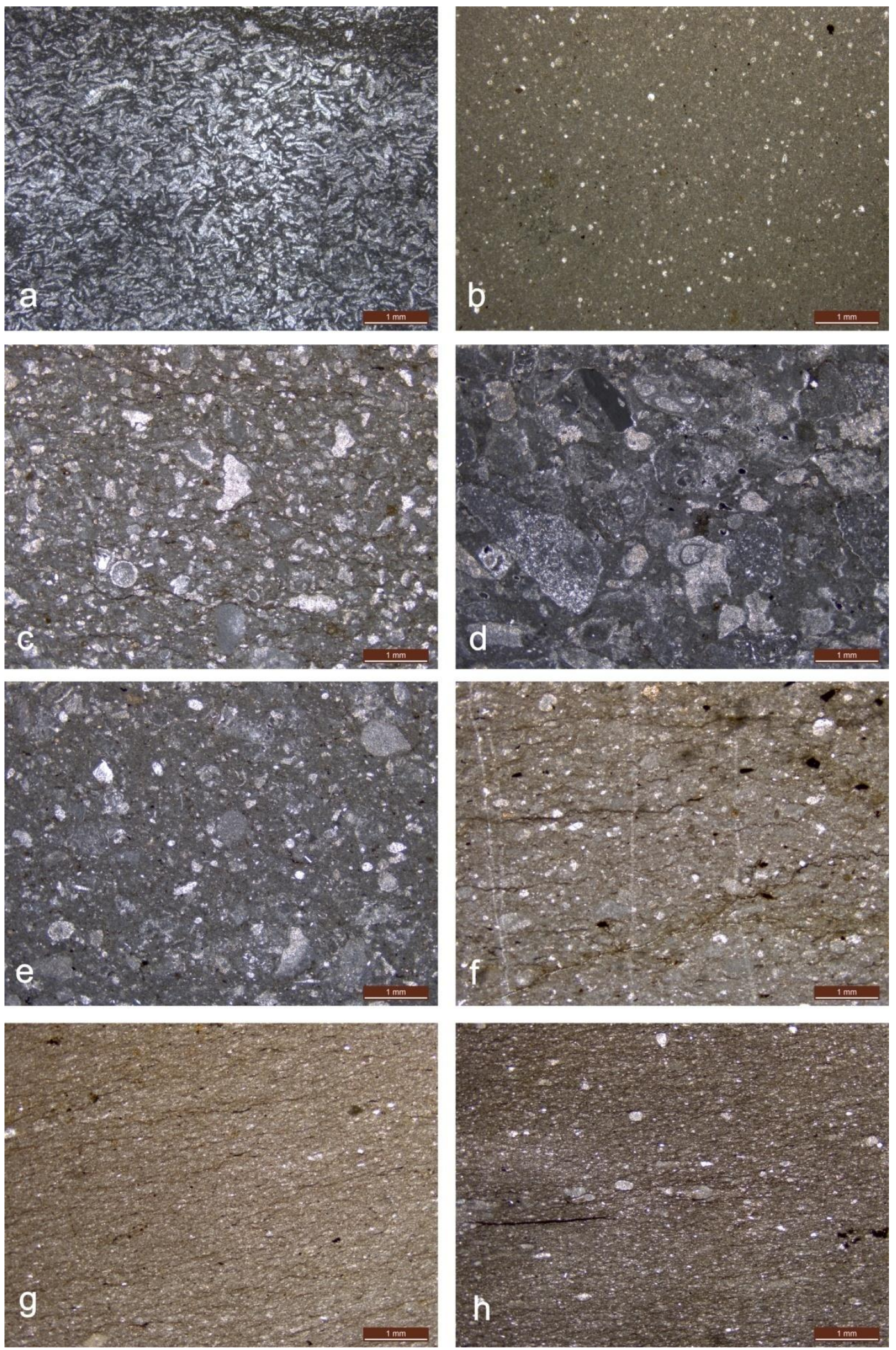

Figure 7. Thin sections plate. (a-b-c) are from Pignola-Abriola, (d-e-f) are from Monte

Volturino, and (g-h) from Madonna del Sirino. (a) Halobia packstone (sample PA6). (b) 
Wackestone with radiolarians and spicules re-crystallized as calcite (sample PA27). (c) Intraclastic packstone, some microstylolites (sample PA15). (d) Volcanic clast-bearing calcarenite or intraclastic-extraclastic packstone (sample MV29). (e) Volcanic clastbearing calcarenite or intraclastic-extraclastic wackestone with radiolarians (sample MV32). (f) Skeletal wackestone with pyritized radiolarians, microstylolites (sample MV37). (g) Grumulous mudstone with few radiolarians; many microstylolites; high clay content (sample MSSS27). (h) Mudstone with oxidized microstylolites (sample MS51a). 


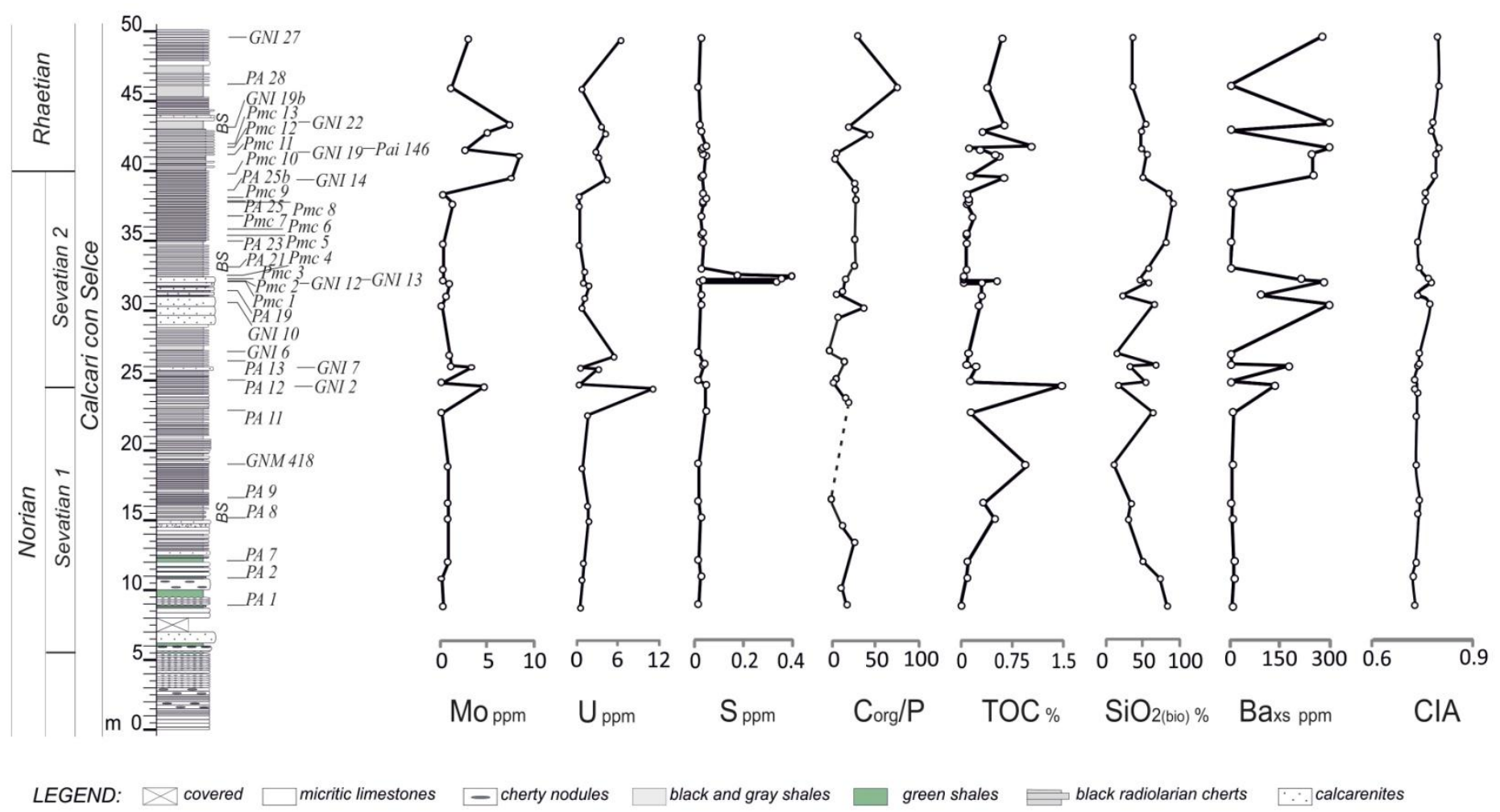

Figure 8. Chemostratigraphy of the Pignola-Abriola section including redox proxies (Mo, U,

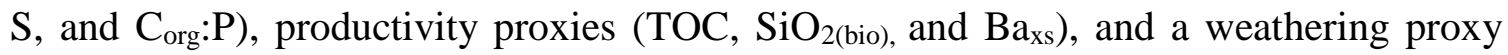
(CIA). BS = black shale units. 


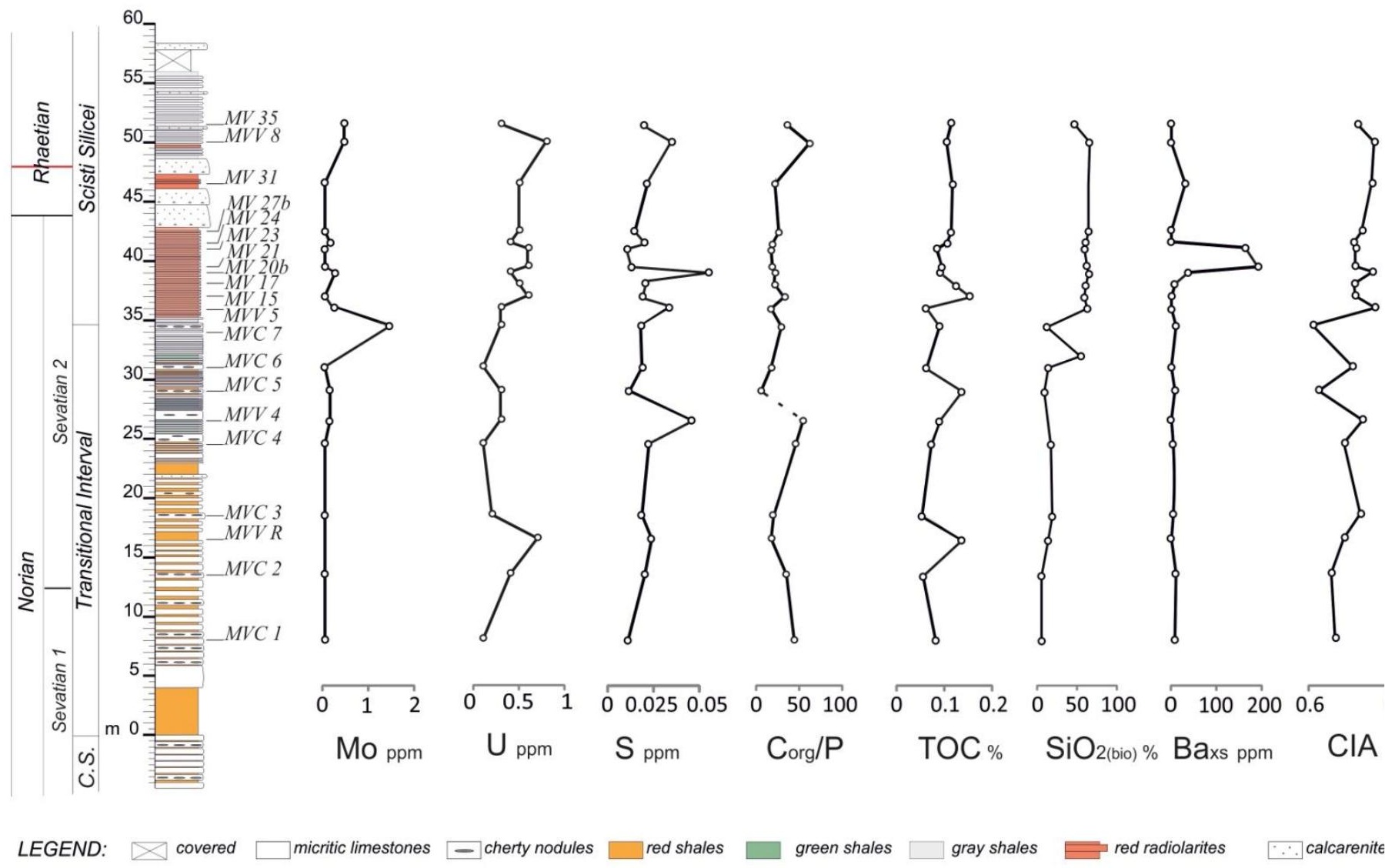

Figure 9. Chemostratigraphy of the Monte Volturino section. C.S. = Calcari con Selce; other details as in Figure 8. 

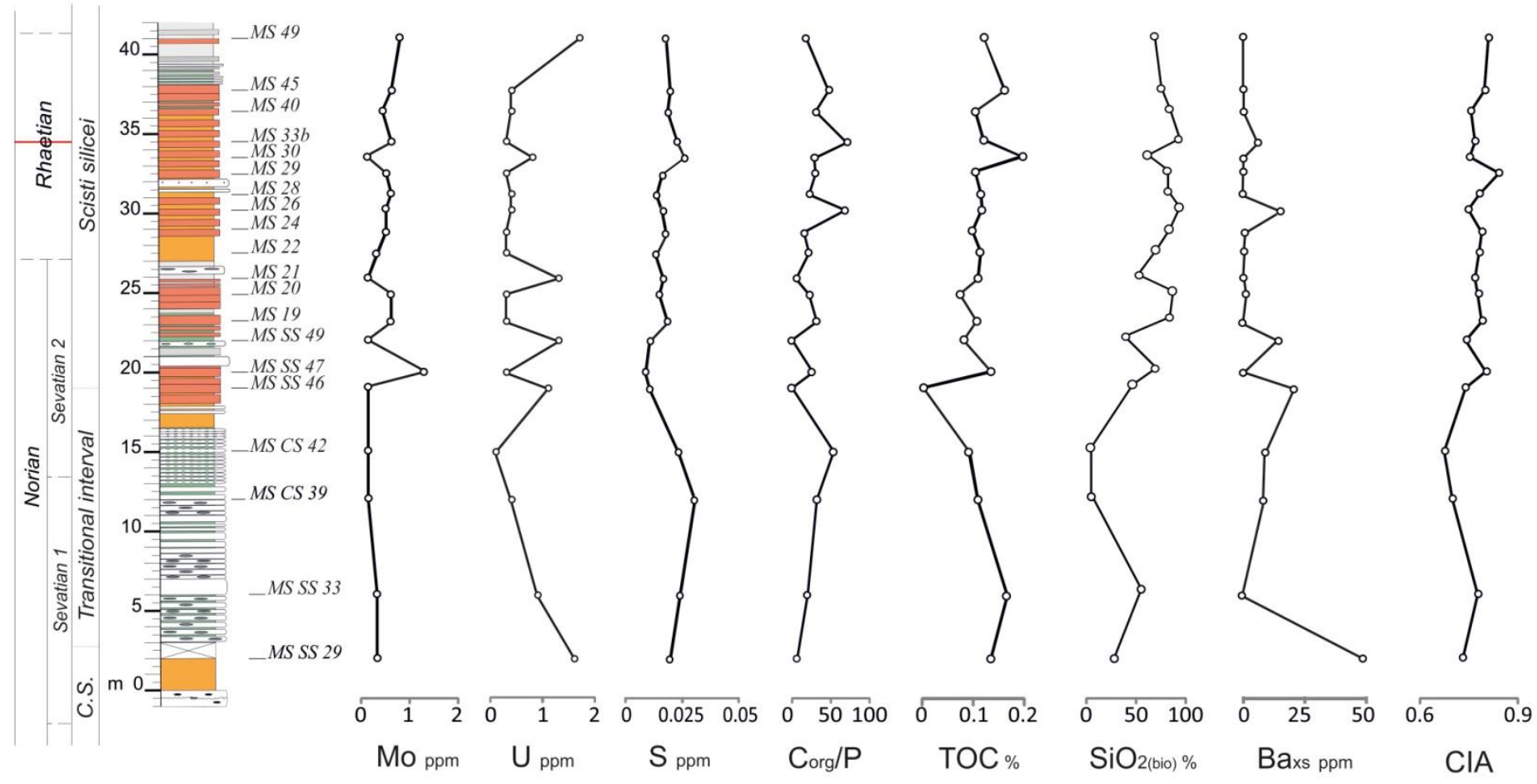

LEGEND:

$\bowtie$ covered

$\square$ micritic limestones $\quad-$ cherty nodules

gray shales $\square$ red shales

$\square$ green shales $\rightleftharpoons$ black radiolarian cherts

Wed radiolarites

$\because$ calcarenites

Figure 10. Chemostratigraphy of the Madonna del Sirino section. C.S. = Calcari con Selce; other details as in Figure 8. 


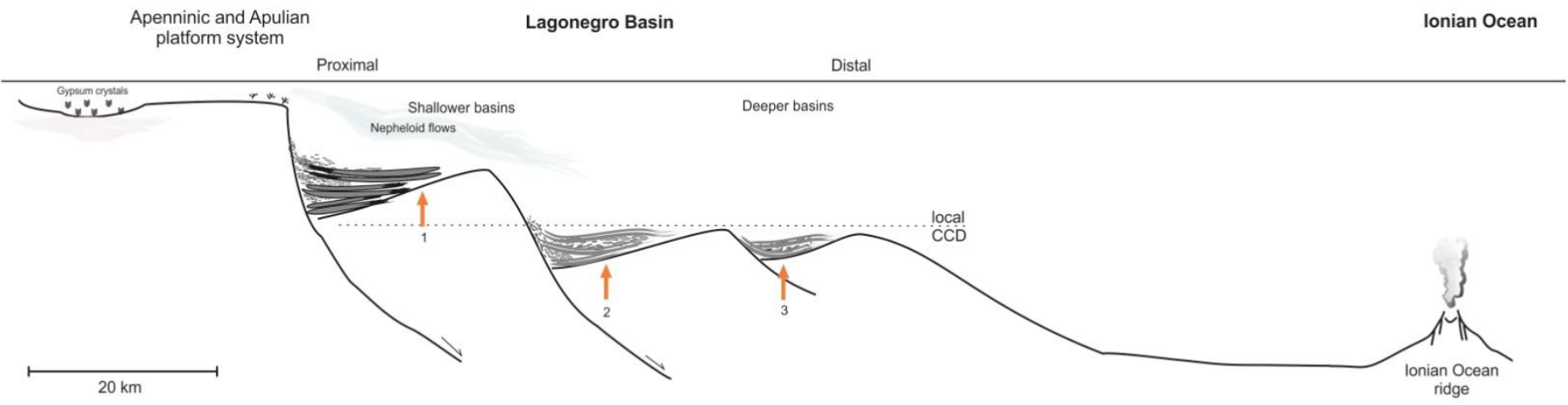

Figure 11. Interpretative depositional model for the Lagonegro Basin during the late Norian to early Rhaetian. Red arrows represent the study sections: $1=$ Pignola-Abriola, $2=$ Monte Volturino, and 3 = Madonna del Sirino. Seafloor bathymetry is interpretative and intended to explain differences in sediment chemistry between the study sections. The distance of the sections from the platform margin is based on the frequency of resedimented carbonates (see Section 5.5 for details). Horizontal scale is approximate and inferred from Scrocca (2010); the CCD depth is local of the Lagonegro Basin only, and inferred from the study of Giordano et al. (2010). 